\title{
Donepezil-based hybrids as multifunctional anti-Alzheimer's disease chelating agents: Effect of positional isomerization
}

Marina Costa, ${ }^{\text {a) }}$ Romane Josselin, ${ }^{\text {a) }}$ Diana F. Silva, b) Sandra M. Cardoso, b),c) Nóra V. May, ${ }^{\text {d) }}$ Sílvia Chaves, a)* ${ }^{*}$. Amélia Santos a) ${ }^{*}$

a) Centro de Quimica Estrutural, Instituto Superior Tecnico, Universidade de Lisboa, Av, Rovisco Pais 1, 1049-001, Lisboa, Portugal

b) CNC-Center for Neuroscience and Cell Biology, University of Coimbra, Coimbra, Portugal

c) Institute of Molecular and Cell Biology, Faculty of Medicine, University of Coimbra, Coimbra, Portugal

d) Research Centre for Natural Sciences, 1117 Magyar tudósok körútja 2 Budapest, Hungary

Keywords: Hydroxyphenyl-benzimidazole; Donepezil; Anti-neurodegeneratives; Alzheimer's disease; Multifunctional drugs; Metal chelation.

* Corresponding authors:

(Sílvia Chaves) E-mail: silvia.chaves@tecnico.ulisboa.pt; Phone: +351-218419269

(M. Amélia Santos) E-mail: masantos@tecnico.ulisboa.pt; Phone: +351-218419273 


\begin{abstract}
The intricate and multifactorial nature of Alzheimer's disease (AD) requires the development of compounds able to hit different pathophysiological targets, such as cholinergic dysfunction, deposits of amyloid- $\beta$ peptide (A $\beta)$ and metal dyshomeostasis. In order to continue the search for new anti-AD drugs, a design strategy was followed based on repositioning donepezil (DNP), by attaching a benzylpiperidine mimetic of DNP moiety at different (ortho, para) attachment points of a hydroxyphenyl-benzimidazole (BIM) chelating unit. Herein, two compounds (1 and 2) are compared in terms of their potential multiple properties: both present good $\mathrm{AChE}$ inhibition (low micromolar range) and are moderate/good inhibitors of $\mathrm{A} \beta$ self- and $\mathrm{Cu}$-mediated aggregation; although compound 1 has a higher chelating capacity towards $\mathrm{Cu}^{2+}(\mathrm{pCu}=14.3, \mathrm{pZn}=6.4, \mathrm{pH}$ 7.4, $\left.C_{\mathrm{L}} / C_{\mathrm{M}}=10, C_{\mathrm{M}}=10^{-6} \mathrm{M}\right)$ than $2(\mathrm{pCu}=10.7, \mathrm{pZn}=6.3)$, attributed to its ability to establish a tridentate $(\mathrm{N}, \mathrm{O}, \mathrm{O})$ coordination to the metal ion. Both compounds are eligible as drug candidates for oral administration but compound 1 shows improved neuroprotective role by completely preventing A $\beta$-induced cell toxicity.
\end{abstract}

\title{
1. Introduction
}

Alzheimer's disease (AD) is one of the most common and devastating age-dependent neurodegenerative disorders and its prevalence is expected to enormously increase in the coming years because of the population growth and ageing [1]. Hence, there has been a worldwide intensive research aimed to understand and find treatment for $\mathrm{AD}$, but no cure has been found so far [2,3]. Currently approved AD therapeutics are only able to attenuate the dementia symptoms by compensating the cholinergic deficit, as the acetylcholinesterase (AChE) inhibitors (tacrine, donepezil, rivastigmine, galantamine) or the glutamate N-methyl D-aspartate (NMDA) receptor antagonist (memantine) [4]. The recognized multifactorial nature and consequent complexity of $\mathrm{AD}$ are believed to account for the absence of disease-modifying drugs. In fact, the formation of misfolded protein aggregates, namely $\beta$-amyloid $(\mathrm{A} \beta)$ plaques (a prominent hallmark of $\mathrm{AD}$ ), dyshomeostasis of metal ions and oxidative stress are among the many factors that are implicated in the trigger and progression of $\mathrm{AD}$ [5]. Furthermore, although $\mathrm{A} \beta$ imbalance has been considered to be a causative agent in $\mathrm{AD}$, high levels of metals (e.g. $\mathrm{Fe}, \mathrm{Cu}, \mathrm{Zn}$ ) have been found in the $\mathrm{A} \beta$ plaques of $\mathrm{AD}$ brains and, in particular, $\mathrm{Cu}$ and $\mathrm{Zn}$ bind to $\mathrm{A} \beta$ peptides, promoting their aggregation, while redox active metal ions (e.g. 
$\mathrm{Cu}, \mathrm{Fe}$ ) promote overproduction of reactive oxygen species (ROS) that can damage biomolecules [6-8]. Therefore, to address the multiple pathological factors and their potential interconnections in $\mathrm{AD}$ pathogenesis, in the last decade there has been a change of paradigm from singletarget drugs towards multi-target drugs as chemical entities (the so called multi-target ligands) able to address multiple biological targets involved in the disease, aimed to get possible therapeutic answers [9-11].

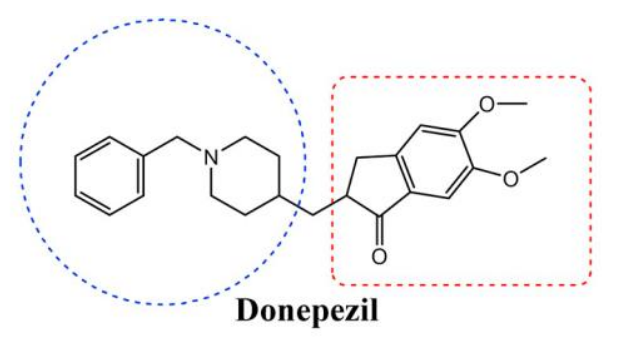

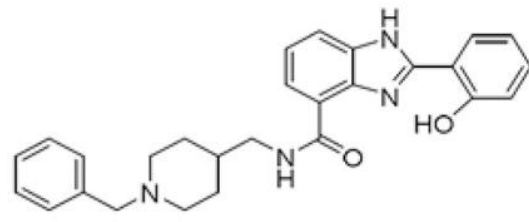

1

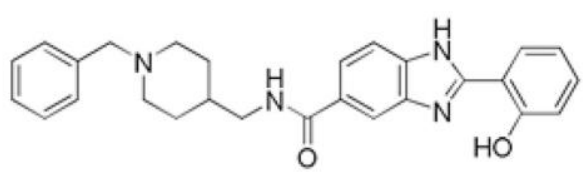

2

Fig 1. DNP and DNP-BIM hybrids (1 and 2), chelators with different attachment points between the benzylpiperidine and the BIM moieties.

In recent years, several research groups, including ours, have developed hybrid compounds, via a rational structure-based methodology which integrates a moiety with capacity for $\mathrm{AChE}$ inhibition with a framework able to interact with $\mathrm{A} \beta$ and also possess metal cheating capacity, so that to associate the symptom treatment with disease modifying roles, namely to inhibit the $\mathrm{A} \beta$ self- and metal-induced aggregation and to attenuate the metal-promoted ROS formation [12-16]. Herein we report the synthesis, physico-chemical and biological evaluation as well as molecular modeling of a new donepezil-hydroxyphenylbenzimidazole (DNP-BIM) chelating hybrid (1) (Fig. 1). This compound results from a structural modification of a recently reported positional isomer DNP hybrid (2) [17], for the sake of increasing ligand denticity and thus improving the metal chelating capacity as well as the control/modulation of interconnected multiple pathological features of $\mathrm{AD}$, namely those that could arise from the synergy of its metal chelation and $\mathrm{A} \beta$ interaction properties. 


\section{Experimental}

\subsection{Chemistry}

\subsubsection{General methods and materials}

Analytical grade reagents were purchased and used as supplied. Solvents were dried according to standard methods [1]. The chemical reactions were monitored by TLC using alumina plates coated with silica gel $60 \mathrm{~F}_{254}$ (Merck). Column chromatography separations were performed on silica gel Merck 230-400 mesh (Geduran Si 60). The melting points (m.p.) were measured with a Leica Galen III hot stage apparatus and are uncorrected. The ${ }^{1} \mathrm{H}$ - and ${ }^{13} \mathrm{C}-\mathrm{NMR}$ spectra were recorded on Bruker AVANCE III spectrometers at 300 and $400 \mathrm{MHz}$, respectively. Chemical shifts $(\delta)$ are reported in ppm from the standard internal reference tetramethylsilane (TMS). The following abbreviations are used: $\mathrm{s}=$ singlet, $\mathrm{d}=$ doublet, $\mathrm{t}=$ triplet, $\mathrm{m}=$ multiplet. Mass spectra (ESI-MS) were performed on a 500 MS LC Ion Trap (Varian Inc., Palo Alto, CA, USA) mass spectrometer equipped with an ESI ion source, operated in the positive or negative ion mode. For the target compounds, the elemental analyses were performed on a Fisons EA1108 CHNS/O instrument at LAIST and were within the limit of $\pm 0.4 \%$. The electronic spectra were recorded with a Perkin Elmer Lambda 35 spectrophotometer, using thermostated $1-\mathrm{cm}$ path length cells and the fluorescence measurements were performed with a Spectramax Gemini EM (Molecular Devices) fluorimeter.

\subsubsection{Synthesis of compound 1}

\subsubsection{2-((1-Benzylpiperidin-4-yl)methyl)isoindoline-1,3-dione (1a)}

Phthalic acid anhydride (1 eq) and 4-(aminomethyl)piperidine (1 eq) were heated at 160 ${ }^{\circ} \mathrm{C}$ for $4 \mathrm{~h}$. The resulting dark brown solid was mixed with $\mathrm{K}_{2} \mathrm{CO}_{3}(6.6 \mathrm{eq})$, triethylamine ( $1.4 \mathrm{eq})$ and benzyl chloride $(2.3 \mathrm{eq})$ and refluxed in acetonitrile for $3 \mathrm{~h}$. Then, the mixture was cooled at rt, added to water, and extracted with ethyl acetate (three times). The organic layers were collected, dried over sodium sulphate anhydrous, and concentrated under reduced pressure. The crude was purified through chromatography column (eluent: $\mathrm{ACN} / \mathrm{H}_{2} \mathrm{O} / \mathrm{NH}_{4} \mathrm{OH}$ 92:8:0.1), affording a white solid ( $\eta=29 \%$ ); M.P. $=130{ }^{\circ} \mathrm{C} .{ }^{1} \mathrm{H} \mathrm{NMR}$ (300 MHz, MeOD-d4), $\delta$ (ppm): 1.37 (m, 2H, Pip), 1.67 (d, 2H, J=12.0 Hz, Pip), 1.80 (m, 1H, Pip), 2.02 (td, 2H, J=12.0 Hz, Pip), 2.91 (d, 2H, J=12.0 Hz, Pip), 3.51 (s, 2H, $\left.\mathrm{NCH}_{2} \mathrm{Ph}\right), 3.58\left(\mathrm{~d}, 2 \mathrm{H}, J=12.0 \mathrm{~Hz}, \mathrm{NCH}_{2} \mathrm{CH}\right), 7.34-7.29(\mathrm{~m}, 5 \mathrm{H}, P h), 7.89-7.79(\mathrm{~m}, 4 \mathrm{H}$, Phth); m/z (ESI-MS): $335.00(\mathrm{M}+\mathrm{H})^{+}$.

\subsubsection{2. (1-Benzylpiperidin-4-yl)methanamine (1b)}


2-((1-Benzylpiperidin-4-yl)methyl)isoindoline-1,3-dione $(1 \quad$ eq $)$ and hydrazine monohydrate (6 eq) were dissolved in absolute ethanol and warmed at $60{ }^{\circ} \mathrm{C}$ for $3 \mathrm{~h}$. The reaction mixture was then filtered and concentrated under reduced pressure. The residue was dissolved in dichloromethane, washed with brine (three times), dried over anhydrous sodium sulphate, and concentrated under reduced pressure obtaining a pure yelloworange oil $(\eta=30.5 \%)$. ${ }^{1} \mathrm{H}$ NMR (300 MHz, MeOD- $\left.d_{4}\right), \delta$ (ppm): 1.01-1.21 (m, 2H, Pip), 1.64 (d, 2H, $J=12.0 \mathrm{~Hz}$, Pip), 1.86 (t, 1H, J=12.0 Hz, Pip), 2.40 (d, 2H, J = $12.0 \mathrm{~Hz}$, Pip), 2.78 (d, 2H, $\left.J=12.0 \mathrm{~Hz}, \mathrm{NCH}_{2} \mathrm{CH}\right) 2.91$ (d, 2H, $J=12.0 \mathrm{~Hz}$, Pip), 3.51 (s, 2H, $\left.\mathrm{NCH}_{2} \mathrm{Ph}\right), 7.34-7.19(\mathrm{~m}, 5 \mathrm{H}, \mathrm{Ph})$

\subsubsection{2-(2-Hydroxyphenyl)-1H-benzo[d]imidazole-4-carboxylic acid (1c)}

To a solution of salicylaldehyde (1 eq) and $\mathrm{Na}_{2} \mathrm{~S}_{2} \mathrm{O}_{5}(1.2$ eq) in the green solvent (glycerol/choline chloride (2:1)) was added the 2,3-diaminobenzoic acid (1 eq). The mixture was heated at $50{ }^{\circ} \mathrm{C}$ for $30 \mathrm{~min}$. Then, the mixture was cooled at $\mathrm{rt}$, added to water and filtrated. The afforded solid was washed with water and then dichloromethane and then purified by recristallisation in EtOAc and $\mathrm{MeOH}$. The title compound was obtained as a purple solid $(\eta=25.2 \%)$, m.p. $>300^{\circ} \mathrm{C}$. ${ }^{1} \mathrm{H}$ NMR $\left(300 \mathrm{MHz}, \mathrm{MeOD}-d_{4}\right), \delta$ (ppm): 7.08 (d, 2H, $J=8.0 \mathrm{~Hz}, B I M) ; 7.42$ (m, 2H, $J=8.0 \mathrm{~Hz}, B I M), 7.96$ (t, 2H, $J=8.0$ Hz, BIM), 8.25 (d, 1H, BIM); m/z (ESI-MS): 253 (M-1)+, $255.00(\mathrm{M}+1)+$.

\subsubsection{3. \\ N-((1-benzylpiperidin-4-yl)methyl)-2-(2-hydroxyphenyl)-1H-}

\section{benzo[d]imidazole-4-carboxamide (1)}

To a solution of the 2-(2-hydroxyphenyl)-1H-benzo[ $d]$ imidazole-4-carboxylic acid (1 eq, 1c) and (1-benzylpiperidin-4-yl)methanamine (1 eq, 2b), in dry DMF, was added $N$ hydroxysuccinimide (1 eq) and DCC (1 eq), and the reaction mixture was left stirring for $24 \mathrm{~h}$ at r.t.. Then the precipitate obtained (urea) was filtered off and the liquid phase was diluted with ethyl acetate and washed with brine (3 times), dried over anhydrous sodium sulfate, concentrated under reduced pressure and purified by recrystallization in EtOAc affording a yellow solid $(\eta=24.2 \%)$; m.p. $=192-193{ }^{\circ} \mathrm{C} .{ }^{1} \mathrm{H}$ RMN (300 MHz, MeOD$d_{4}$ ), $\delta$ (ppm): 1.75-1.95 (m, 5H, Pip), 2.17 (t, 2H, J=12 Hz, Pip), 3.02 (d, 2H, J=12 Hz, Pip), 3.49 (d, 2H, $J=6 \mathrm{~Hz}, \mathrm{CH}_{2} \mathrm{NCO}$ ), 3.60 (s, 2H, $\mathrm{CH}_{2} \mathrm{Ph}$ ), 7.00-7.08 (m, 2H, Ph), 7.28$7.42(\mathrm{~m}, 7 \mathrm{H}, P h), 7.79$ (d, 1H, J=9 Hz, BIM), 7.89 (d, 1H, J=8 Hz, BIM), 8.16 (d, 1H, $J=9 \mathrm{~Hz}, B I M) .{ }^{13} \mathrm{C} \mathrm{RMN}\left(100 \mathrm{MHz}, \mathrm{MeOD}-d_{4}\right), \delta$ (ppm): 29.25, 33.35, 44.31, 52.77, $62.44,116.65,119.45,119.54,122.13,127.18,127.59,127.84,129.50,129.59,131.84$, 
131.91, 135.91, 136.56, 139.11, 139.33, 151.40, 157.44, 161.38; m/z (ESI-MS): 439.00 (M-1), $441.00(\mathrm{M}+1)$.

\subsection{Molecular modeling for ligand-AChE docking}

To perform the ligand-enzyme docking studies, the X-ray crystallographic structure of Torpedo californica-AChE (TcAChE) complexed with an inhibitor (donepezil, Dnp) was taken from RCSB Protein Data Bank (PDB entry 1 EVE) [2], in order to be used as enzyme model. This structure was chosen because of the similarity between the original inhibitor (DNP) and ligands $\mathbf{1}$ and 2, namely relatively to the benzylpiperidine moieties. The original structure was treated using Maestro v. 9.3 [3] by removing the original ligand, solvent, and co-crystallization molecules, and then adding the hydrogen atoms. The ligands were built using Maestro, and then, using Ghemical v. 2.0 [4], they were submitted to random conformational search (RCS) of 1000 cycles, and 2500 optimization steps using Tripos 5.2 force field [5]. The minimized ligands were docked into the AChE structure with GOLD software v. 5.1 [6], and the zone of interest was defined as the residues within $10 \AA$ from the original position of the ligand in the crystal structure. The 'allow early termination' option was deactivated and the remaining default parameters of Gold were used. The ligands were subjected to 100 genetic algorithm steps using ASP as fitness function.

\subsection{Prediction of pharmacokinetic properties}

To analyze the drug like behavior of the DNP-BIM hybrids, the prediction of their main pharmacokinetic properties was performed in silico. This procedure determined parameters such as the lipo-hydrophilic character $(c \log P)$, blood-brain barrier partition coefficient $(\log \mathrm{BB})$, the ability to be absorbed through the intestinal tract (Caco-2 cell permeability) and CNS activity.

The ligands were built and minimized as previously mentioned for the docking studies. The structures were submitted to the calculation of these relevant pharmacokinetic properties and descriptors using QikProp v. 2.5 [7]. These predictions are for orally delivered drugs and assume non-active transport.

\subsection{Metal chelation studies}

\subsubsection{Potentiometric and UV-vis spectrophotometric titrations}


Solutions. The aqueous copper $\left(\mathrm{CuCl}_{2}, 0.015 \mathrm{M}\right)$ and zinc $\left(\mathrm{ZnCl}_{2}, 0.0156 \mathrm{M}\right)$ stock solutions for potentiometric and spectrophotometric equilibrium studies were prepared from $1000 \mathrm{ppm}$ standards (Titrisol) and their metal content was evaluated by atomic absorption. The titrant solution $(0.1 \mathrm{M} \mathrm{KOH})$ was obtained from a carbonate-free commercial concentrate (Titrisol) and standardized by potentiometric titration with potassium hydrogen phthalate. The titrant solution was discarded whenever the percentage of carbonate (Gran's method) [8] was about $0.5 \%$ of the total amount of base. Measurements. Compound 1 was titrated in $50 \%(w / w) ~ D M S O / \mathrm{H}_{2} \mathrm{O}$ medium, at $T=25.0$ $\pm 0.1{ }^{\circ} \mathrm{C}$ and ionic strength $(I) 0.1 \mathrm{M} \mathrm{KCl}$, by using $0.1 \mathrm{M} \mathrm{KOH}$ as titrant. Both glass and $\mathrm{Ag} / \mathrm{AgCl}$ reference electrodes were previously conditioned in $\mathrm{DMSO} / \mathrm{H}_{2} \mathrm{O}$ mixtures with increasing amount of DMSO and the response of the glass electrode was controlled by strong acid - strong base $(\mathrm{HCl} / \mathrm{KOH})$ calibrations with the determination of the Nernst parameters by Gran's method [8]. The measurements were performed in a final volume of $30.00 \mathrm{~mL}$, with the ligand concentrations $\left(C_{\mathrm{L}}\right) 6.7 \times 10^{-4} \mathrm{M}$ (potentiometry) and $4.0 \times$ $10^{-5} \mathrm{M}$ (spectrophotometry), under different $C_{\mathrm{M}} / C_{\mathrm{L}}$ ratios: 0:1 $(\mathrm{L}), 1: 1$ and 1:2 $(\mathrm{M}=\mathrm{Cu}$, $\mathrm{Zn})$. The spectrophotometric measurements were carried out at $\mathrm{pH}$ ca 2.5-11.5, in the $300-420 \mathrm{~nm}$ wavelength range. All titrations were performed in duplicate and under the stated experimental conditions the $\mathrm{p} K_{\mathrm{w}}$ value (13.6) was determined and subsequently used in the computations. The stepwise protonation constant of the ligand, $K_{i}=\left[\mathrm{H}_{\mathrm{i}} \mathrm{L}\right] /\left[\mathrm{H}_{\mathrm{i}}\right.$ $\left.{ }_{1} \mathrm{~L}\right][\mathrm{H}]$, and the overall metal-complex stability constants, $\beta_{\mathrm{M}_{\mathrm{m}} \mathrm{H}_{\mathrm{h}} \mathrm{L}_{1}}=$ $\left[\mathrm{M}_{\mathrm{m}} \mathrm{H}_{\mathrm{h}} \mathrm{L}_{1}\right] /[\mathrm{M}]^{\mathrm{m}}[\mathrm{H}]^{\mathrm{h}}[\mathrm{L}]^{1}$, were calculated by fitting the potentiometric and spectrophotometric data with, respectively, Hyperquad 2008 [9] and PSEQUAD programs [10]. The metal hydrolysis constants were determined under the defined experimental conditions $\left(I=0.1 \mathrm{M} \mathrm{KCl}, 50 \% \mathrm{w} / \mathrm{w} \mathrm{DMSO} / \mathrm{H}_{2} \mathrm{O}, \mathrm{T}=25.0 \pm 0.1{ }^{\circ} \mathrm{C}\right)$ and the following values of stability constants were included in the fitting of experimental data towards the equilibrium models related to the $\mathrm{Cu}^{2+} / \mathrm{L}$ and $\mathrm{Zn}^{2+} / \mathrm{L}$ systems: $\log \beta_{\mathrm{Cu}_{2} \mathrm{H}_{-2}}$ $=-9.99 ; \log \beta_{\mathrm{ZnH}-2}=-14.79, \log \beta_{\mathrm{ZnH}-3}=-23.48$. Species distribution curves were plotted with the Hyss program [9].

\subsubsection{ESI-MS spectra}

The $\mathrm{pH}$ of the $\mathrm{Cu}(\mathrm{II}) / \mathbf{1}\left(C_{\mathrm{L}}=2.25 \times 10^{-4} \mathrm{M}\right)$ and $\mathrm{Zn}(\mathrm{II}) / \mathbf{1}\left(C_{\mathrm{L}}=2.25 \times 10^{-4} \mathrm{M}\right)$ systems in $50 \% \mathrm{w} / \mathrm{w} \mathrm{DMSO} /$ water medium was previously ascertained to $4.28\left(C_{\mathrm{L}} / C_{\mathrm{Cu}}=1\right)$ and $6.42\left(C_{\mathrm{L}} / C_{\mathrm{Cu}}=2\right)$, as well as to 7.01 and $8.39\left(C_{\mathrm{L}} / C_{\mathrm{Zn}}=2\right)$, by using $\mathrm{KOH}$ solution, and the respective mass spectra were obtained from a LCQ Fleet mass spectrometer operated 
in the ESI positive and negative ion mode (Thermo Scientific). The optimized parameters were as following: ion spray voltage, $+4.5 /-2.5 \mathrm{kV}$; capillary voltage, $16 /-28 \mathrm{~V}$; tube lens offset, $-63 \mathrm{~V}$; sheath gas $\left(\mathrm{N}_{2}\right), 80$ arbitrary units; auxiliary gas, 5 arbitrary units; capillary temperature, $250{ }^{\circ} \mathrm{C}$. The spectra were recorded in the range $100-1000$ Da. Spectra typically correspond to the average of 20-35 scans.

\subsubsection{EPR spectra}

CW-EPR spectra were recorded with a BRUKER EleXsys E500 spectrometer (microwave frequency $9.85 \mathrm{GHz}$, microwave power $10 \mathrm{~mW}$, modulation amplitude $5 \mathrm{G}$, modulation frequency $100 \mathrm{kHz}$ ). Two samples were prepared for each compound (1 and 2), one at ligand excess and another around equimolar concentration in $50 \% \mathrm{w} / \mathrm{w}$ DMSO/water solution. The $\mathrm{pH}$ of the $\mathrm{Cu}(\mathrm{II}) / \mathbf{1}\left(C_{\mathrm{L}}=1.48 \times 10^{-3} \mathrm{M}\right)$ system was ascertained to $6.75\left(C_{\mathrm{L}} / C_{\mathrm{Cu}}=1\right)$ and $6.91\left(C_{\mathrm{L}} / C_{\mathrm{Cu}}=1.5\right)$, while that of the $\mathrm{Cu}(\mathrm{II}) / 2\left(C_{\mathrm{L}}=\right.$ $\left.2.23 \times 10^{-3} \mathrm{M}\right)$ system was to $5.46\left(C_{\mathrm{L}} / C_{\mathrm{Cu}}=1\right)$ and $5.72\left(C_{\mathrm{L}} / C_{\mathrm{Cu}}=2\right)$, by using $\mathrm{KOH}$ solution. Room temperature spectra were measured in capillary at $298 \mathrm{~K}$. Anisotropic EPR spectra were recorded in quartz EPR tubes immersed in a Dewar containing liquid nitrogen $(77 \mathrm{~K}) ; 0.025 \mathrm{~mL} \mathrm{MeOH}$ was added to the $0.2 \mathrm{~mL}$ sample to avoid water crystallization upon freezing. All recorded EPR spectra, and anisotropic EPR spectra at $77 \mathrm{~K}$, were simulated by the EPR program [11]. To describe the isotropic spectra the parameters $g_{0}, A_{0}{ }^{\mathrm{Cu}}$ copper hyperfine $\left(\boldsymbol{I}_{\boldsymbol{C} \boldsymbol{u}}=3 / 2\right)$ and $\boldsymbol{a}_{0}{ }^{\boldsymbol{N}}$ nitrogen $\left(\boldsymbol{I}_{\boldsymbol{N}}=1\right)$ superhyperfine couplings have been taking into account. The four copper(II) linewidths were treated with individual linewidth parameters. The g-tensor $\left(g_{x}, g_{y}, g_{z}\right)$, copper hyperfine tensor $\left(A_{x}{ }^{C u}\right.$, $\left.A_{y}{ }^{C u}, A_{z}{ }^{C u}\right)$ and nitrogen hyperfine tensor $\left(a_{x}{ }^{N}, a_{y}{ }^{N}, a_{z}{ }^{N}\right.$, for wich $\mathrm{x} y$ and $\mathrm{z}$ denotes the directions of the g-tensor) parameters were fitted. For the description of the linewidth the orientation dependent $\alpha, \beta$ and $\gamma$ parameters were used to set up each component spectra. Since a natural copper(II)chloride was used for the measurements, both the isotropic and anisotropic spectra were calculated as the sum of the spectra of ${ }^{63} \mathrm{Cu}$ and ${ }^{65} \mathrm{Cu}$ weighted by their natural abundances. The hyperfine and super-hyperfine coupling constants and the relaxation parameters were obtained in field units (Gauss $=10^{-4} \mathrm{~T}$ ).

\subsubsection{Molecular modeling of the copper complexes}

In the absence of X-ray structure, a molecular modelling study was performed aimed at providing some further insight into the 1:1 (M/L) copper complex structures of compounds 1 and 2, considering, respectively, one and two water molecules in the 
coordination shell. These studies were carried out with full geometry optimization of the $\mathrm{Cu}$ (II) complexes by quantum mechanical calculations based on DFT methods included in the Gaussian 03 program software [12] with the B3PW91 hybrid functional. Preliminary molecular simulation was obtained by using 3-21G basis set and afterwards 6-31G**. No symmetry constrains were enforced during geometry optimization with the two basis sets. The calculations were performed as well for one water molecule by using the B3PW91 functional, first with the 3-21G basis set and subsequently re-optimized via 6-31G** basis set. Frequency calculations were performed to confirm the nature of the minima. The electronic energies $\left(E_{\mathrm{b} 1}\right)$ obtained at the PBE0/b1 level of theory were converted to free energy $\left(G_{\mathrm{b} 1}\right)$ at $298.15 \mathrm{~K}$ and 1 atm by using zero point energy and thermal energy corrections based on structural and vibration frequency data calculated at the same level.

\subsection{Biological studies}

\subsubsection{Acetylcholinesterase inhibition}

The enzymatic activity of AChE was determined using an adaptation of Ellman's method, as already described $[13,14]$. Firstly, a stock solution of AChE was prepared by dissolving enzyme $500 \mathrm{U}$ in $10 \mathrm{~mL}$ of tris(hydroxymethyl)aminomethane (TRIS) buffer (50 mM, $\mathrm{pH}$ 8). Then, 4-(2-hydroxyethyl)-1-piperazineethanesulfonic acid (HEPES) buffer was used for further dilution of the enzyme solution therefore obtaining the final working solution of AChE. The assay solution consisted of $374 \mu \mathrm{L}$ of HEPES buffer (50 mM and $\mathrm{pH} 8.0)$, a variable volume $(10-50 \mu \mathrm{L})$ of the compound's stock solution $(1 \mathrm{mg} / \mathrm{mL}$ of $\mathrm{MeOH}$ ), $476 \mu \mathrm{L}$ of $3 \mathrm{mM}$ bis(3-carboxy-4-nitrophenyl) disulfide (DTNB), $25 \mu \mathrm{L}$ of AChE stock solution and the necessary amount of methanol to attain the same volume of sample mixture in a $1 \mathrm{~mL}$ cuvette. After mixing, samples were left to incubate for $15 \mathrm{~min}$ and then $75 \mu \mathrm{L}$ of $16 \mathrm{mM}$ acetylthiocholine iodide (AChI) solution was added and immediately the reaction was monitored at $405 \mathrm{~nm}$ for $5 \mathrm{~min}$. Firstly, enzyme activity was determined by measuring the rate of enzymatic reaction in solution by recording absorbance (with or without enzyme) at $405 \mathrm{~nm}$. To calculate the percent inhibition of $\mathrm{AChE}$, the enzyme activity in the presence of increasing concentrations of the test compound, as well as for a blank reaction (methanol without compounds), were measured at $405 \mathrm{~nm}$. 
The obtained results were expressed in percentage of inhibition through the Eq. (1):

$$
\% I=100-\left(v_{l} / v_{0} \times 100\right)
$$

Where $v_{l}$ is the initial reaction rate in the presence of the inhibitor and $v_{0}$ is the initial rate of the control reaction. The curves of inhibition were obtained using a plot of percentage of enzymatic inhibition versus inhibitor concentration, and a calibration curve was obtained from which the linear regression parameters were obtained.

\subsubsection{Inhibition of self- and $\mathrm{Cu}^{2+}$-mediated $\mathrm{A} \beta$ aggregation}

Amongst the methods used to measure the aggregation of $A \beta_{1-42}$, the assay based on Thioflavin $\mathrm{T}$ (ThT) is the standard procedure $[15,16]$. This test is performed with $A \beta_{1-42}$ peptide previously prepared by dissolving it in 1,1,1,3,3,3-hexafluoro-2-propanol (HFIP), an organic solvent useful to solubilize and monomerize the $\beta$-sheet protein aggregates and reserve them in the fridge. Films are re-dissolved in an Eppendorf tube with a fresh solution of a mixture of $\mathrm{CH}_{3} \mathrm{CN} / \mathrm{Na}_{2} \mathrm{CO}_{3} / \mathrm{NaOH}$, to have a stable stock solution, and, afterwards, added to an optimized fibrillation phosphate buffer. The samples must be prepared using $\mathrm{MeOH}(1 \mathrm{mg} / \mathrm{mL})$ as a solvent with the specific procedure, followed by incubation in a water bath for $24 \mathrm{~h}$ at $37^{\circ} \mathrm{C}$ with gentle shaking. After incubation, the samples were added to a 96-well plate (BD Falcon) with $180 \mu \mathrm{L}$ of $5 \mu \mathrm{M}$ ThT in $50 \mathrm{mM}$ glycine- $\mathrm{NaOH}$ ( $\mathrm{pH} 8.5$ ) buffer. Blank samples were prepared for each concentration in a similar way, devoid of peptide. After 5-min incubation with the dye, the ThT fluorescence was measured at $446 \mathrm{~nm}$ (excitation) and $485 \mathrm{~nm}$ (emission).

\subsubsection{Cell viability and neuroprotection}

SH-SY5Y human neuroblastoma cell line (ATCC-CRL-2266) is grown in Dulbecco's modified Eagle's medium (DMEM), and were obtained from Gibco-Invitrogen (Life Technologies Ltd, UK) with 10\% heat inactivated fetal calf serum, containing $50 \mathrm{U} / \mathrm{mL}$ penicillin and $50 \mu \mathrm{g} / \mathrm{mL}$ streptomycin, under a humidified atmosphere of $95 \%$ air- $5 \%$ $\mathrm{CO}_{2}$ at $37^{\circ} \mathrm{C}$. Cells were plated at $0.12 \times 10^{6}$ cells $/ \mathrm{mL}$ for cell viability assay. The tested compounds were dissolved in DMSO at a concentration of $50 \mathrm{mM}$ and aliquots were stored at $-20{ }^{\circ} \mathrm{C}$. We performed a dose-response screening (from $10 \mu \mathrm{M}$ to $40 \mu \mathrm{M}$ ) in order to choose the highest non-toxic concentration. As a result we selected: $20 \mu \mathrm{M}$ final concentrations for compounds 18, 19, 20 and 23; $20 \mu \mathrm{M}$ final concentrations for compound 19; $35 \mu \mathrm{M}$ final concentration for compounds 21 and 24. The final concentration of DMSO in culture media did not exceed $0.05 \%(\mathrm{v} / \mathrm{v})$ and no alterations on cells were observed. The compounds were added to the cell media $1 \mathrm{~h}$ before the 
incubation with $A \beta_{1-42}$ or L-ascorbic acid/ferrous sulfate. $A \beta_{1-42}$ or L-ascorbic acid/ferrous sulfate where incubated alone or with the compound for an additional $24 \mathrm{~h}$. A $\beta_{1-42}$ was prepared as $276.9 \mu \mathrm{M}$ stock in sterile water and added to the medium at $2.5 \mu \mathrm{M}$ final concentration. Ferrous sulfate was freshly prepared as $0.36 \mathrm{M}$ stock in water and added to the medium at $500 \mu \mathrm{M}$ final concentration. $L$-Ascorbic Acid was freshly prepared as $80 \mathrm{mM}$ stock in water and added to the medium at $5 \mathrm{mM}$ final concentration. $\mathrm{A} \beta_{1-42}$ was purchased from Bachem (Torrance, CA, USA) and ferrous sulfate and L-ascorbic acid from Sigma Chemical Co (St. Louis, MO, USA).

Cell viability was determined by the MTT (3-(4,5-dimethylthiazol-2-yl)-2,5diphenyltetrazolium bromide) reduction test. In viable cells, the enzyme succinate dehydrogenase metabolizes MTT into a formazan that absorbs light at $570 \mathrm{~nm}$. Following the cell treatment protocol, the medium was aspirated and $0.5 \mathrm{~mL} \mathrm{MTT}(0.5 \mathrm{mg} / \mathrm{mL})$ was added to each well. The plate was then incubated at $37^{\circ} \mathrm{C}$ for $1 \mathrm{~h} 30 \mathrm{~min}$ protected from light. At the end of the incubation period, the formazan precipitates were solubilized with $0.5 \mathrm{ml}$ of acidic isopropanol $(0.04 \mathrm{M} \mathrm{HCl} /$ isopropanol $)$. The absorbance was measured at $570 \mathrm{~nm}$ [17]. Cell reduction ability was expressed as a percentage of untreated control cells.

All data were expressed as mean \pm S.E.M. of at least three independent experiments performed in duplicates. Statistical analyses were performed using GraphPad Prism 5 (GraphPad Software, San Diego, CA, USA). Differences between two datasets were evaluated by two-tailed unpaired Student's t test A $P$ - value $<0.05$ was considered statistically significant.

\section{Results and Discussion}

\subsection{Synthesis of compound 1}

The synthesis of compound $\mathbf{1}$ involved the synthetic strategy summarized in Scheme 1, while the synthesis of compound 2 was previously reported [20]. 


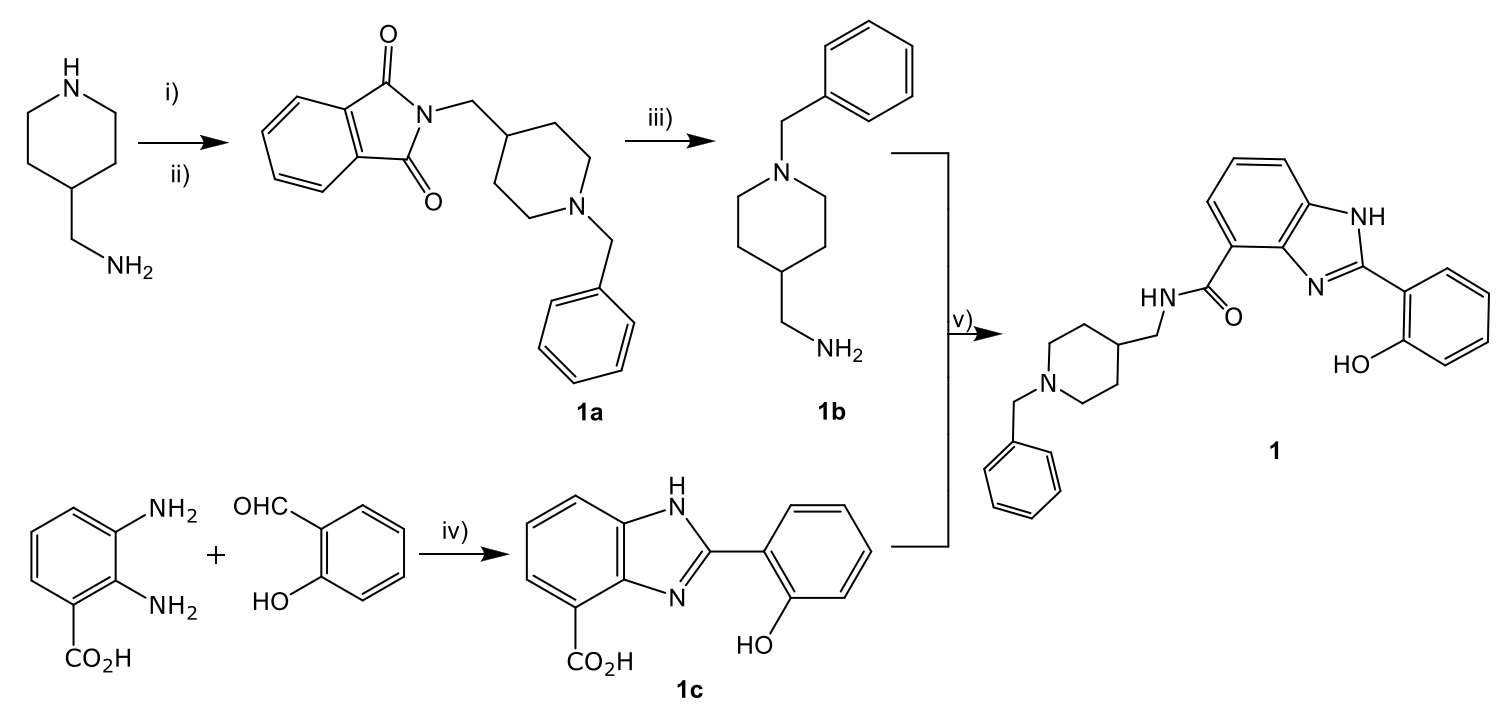

Scheme 1. Reagents and conditions: i) phthalic anhydride, $160{ }^{\circ} \mathrm{C}, 4 \mathrm{~h}$; ii)) benzyl bromide, $\mathrm{K}_{2} \mathrm{CO}_{3}$, triethylamine, acetonitrile, $50{ }^{\circ} \mathrm{C}, 3 \mathrm{~h}$; (iii) $\mathrm{N}_{2} \mathrm{H}_{4} \mathrm{XH}_{2} \mathrm{O}$, absolute ethanol, reflux, $3 \mathrm{~h}$, then RT, overnight; iv) dimethylacetamide, $\mathrm{Na}_{2} \mathrm{~S}_{2} \mathrm{O}_{5}, 100^{\circ} \mathrm{C}, 12 \mathrm{~h}$; v) DCC, $N$-hydroxysuccinimide, dry DMF, RT, $24 \mathrm{~h}$.

This involved the synthesis of two main frameworks, a benzyl-piperidine-methanamine (1b) and carboxylic derivative of benzimidazole (1c), as well as their attachment through an amidic linkage. The preparation of $\mathbf{1 b}$ involved a 3 -step reaction. Firstly, the the primary amine group of the commercially available piperidinemethanamine was protected, as a phthalimide group, by reaction with phthalic anhydride, followed by the piperidine $N$-benzylation, by reaction with benzyl bromide in basic conditions, affording 1a. This was subsequently released from phthalimide group by reaction with hydrazine hydrate in absolute ethanol, affording the free amine derivative (1b). Parallely, The hydroxyphenylbenzimidazole carboxylic acid (1c) was prepared by Mannich reaction between 3,4-diamino benzoic acid and salicylaldehyde and cyclization in the presence of the reducing agent sodium metabissulfite [19]. Finally the intermediates $\mathbf{1 b}$ and $\mathbf{1 c}$ were coupled to each other via amide bond formation, affording the novel hybrid $\mathbf{1}$. This reaction was carried out in dry DMF with NHS and DCC as activators, under $\mathrm{N}_{2}$ atmosphere for two days.

\subsection{Molecular design and modeling studies of ligand-AChE interactions}

DNP is undoubtedly a contemporary choice as anti-AD drug and therefore it was herein used as an inspiration to design the new hybrid 1. In this way, N-benzylpiperidine was enclosed in the structure of the hybrid and further connected to a hydroxyphenylbenzimidazole (BIM) unit. The N-benzylpiperidine portion mimics the binding interaction of DNP within the catalytic anionic site (CAS) of AChE [12] while the BIM 
moiety is expected to mimic the indanone segment of DNP in its interaction with the peripheral anionic site (PAS) of the enzyme, besides providing additional properties to the hybrids, such as anti-A $\beta 42$ aggregation and metal chelating activity $[16,17,40,41]$. It is well known that DNP establishes a strong interaction within the active site of human acetylcholine esterase, hAChE, and also of the electric ray homologue (Torpedo californica), TcAChE. Notwithstanding some differences between the respective inhibitor-enzyme complexes, both enzymes are fairly conservative in terms of the main aminoacid residues that coat the active site gorge [42] and so the herein described modeling study was performed with TcAChE.
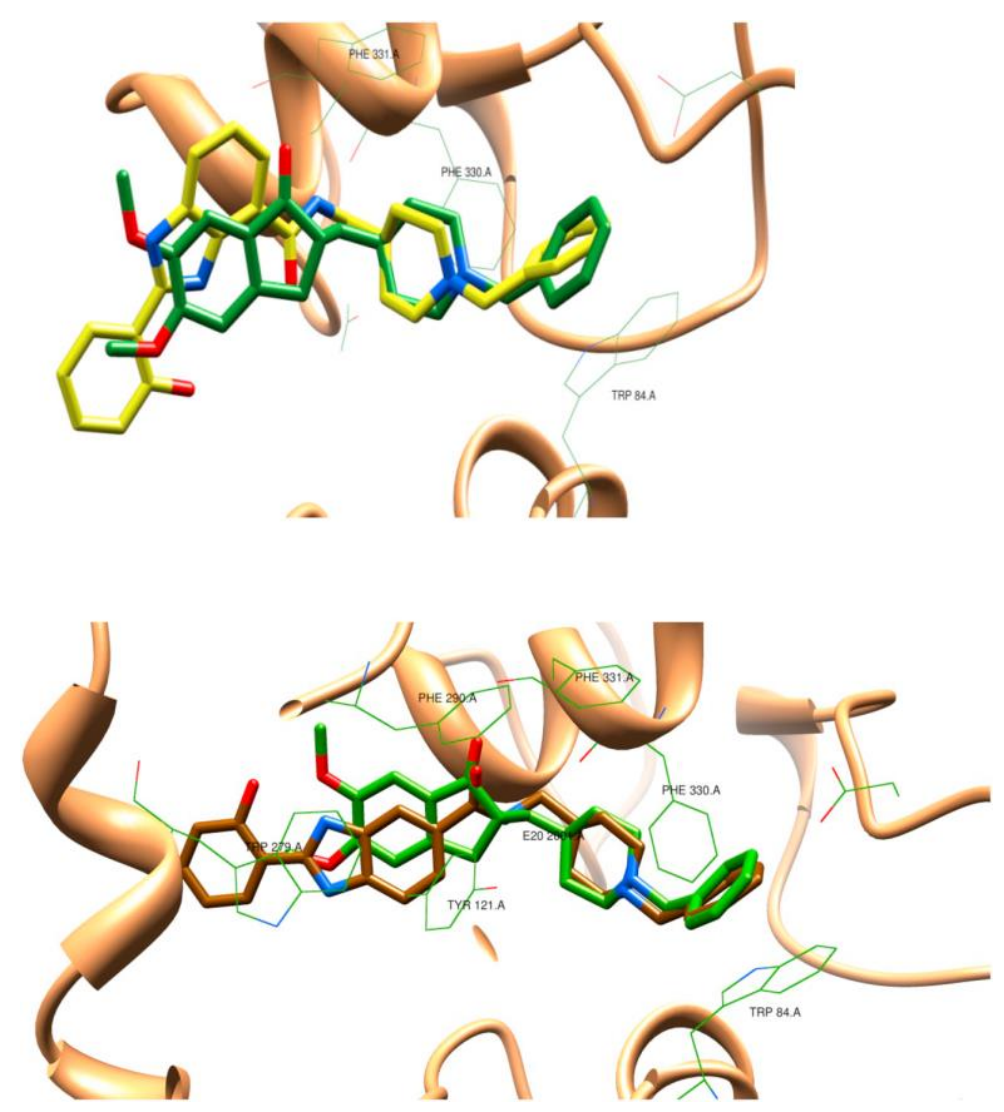

Fig. 2. Superposition of compound 1 (above) and 2 [17] (below) and the original ligand (DNP), from PDB code 1EVE, inside the TcAChE active site: DNP (green), compound 1 (yellow) and compound 2 (brown).

The binding of DNP to TcAChE includes three types of interactions: in the bottom of the gorge, the benzyl group establishes a parallel $\pi-\pi$ stacking with the indole group of Trp84; in the middle of the gorge, the charged nitrogen atom can establish a cation- $\pi$ binding interaction with the phenyl group of Phe330; at the entrance of the gorge, the indanone ring interacts through $\pi-\pi$ stacking with the peripheral anionic residue Trp279. The 
docking simulations with compounds 1 and 2 show some differences in their accommodation inside the gorge of the enzyme, namely concerning the interaction of the benzylpiperidine moiety with the aminoacid residues of CAS: in the case of compound 2 there is an excellent superimposition with the original ligand (DNP), while compound 1, thought it can establish identical binding through the piperidine nitrogen atom, it slightly deviates from the position of the original ligand (see Fig. 2). On the other way, the BIM moieties of both compounds seem to be involved quite similarly in the interactions with PAS, allowing a $\pi-\pi$ interaction with the indole group from Trp279, although probably with a less favorable orientation than DNP. This fact is eventually due to the larger size of the BIM unit when compared with that of the indanone group of DNP. Therefore, as a conclusion, the modeling studies seem to predict that the ortho compound 1 is a less good AChE inhibitor than its positional isomer (compound 2).

\subsection{Acid-base properties}

The chelating capacity of compound 1, with the BIM unit ortho-attached to the benzylpiperazinic moiety, was studied by $\mathrm{pH}$-potentiometric $\left(\mathrm{M}=\mathrm{Cu}^{2+}, \mathrm{Zn}^{2+}\right)$ as well as ultraviolet-visible (UV-vis in the case of $\mathrm{Cu}^{2+}$ system) spectrophotometric titrations for the different $\mathrm{M} / \mathrm{L}$ systems: 0:1, 1:1 and 1:2. A 50\% w/w DMSO/water medium was adopted to perform these studies, due to some solubility problems of the compound. Nevertheless, in terms of cellular studies, the amount of ligand used is lower $(<7 \mu \mathrm{M})$ and so the final concentration of DMSO employed in culture media would be even inferior $(<1 \%)$, therefore not expecting to involve modifications in biological tissues. In order to establish the metal chelating model, first the protonation constants of 1 were determined by both above referred experimental techniques (see Fig. 1) and the values obtained are contained in Table 1. 

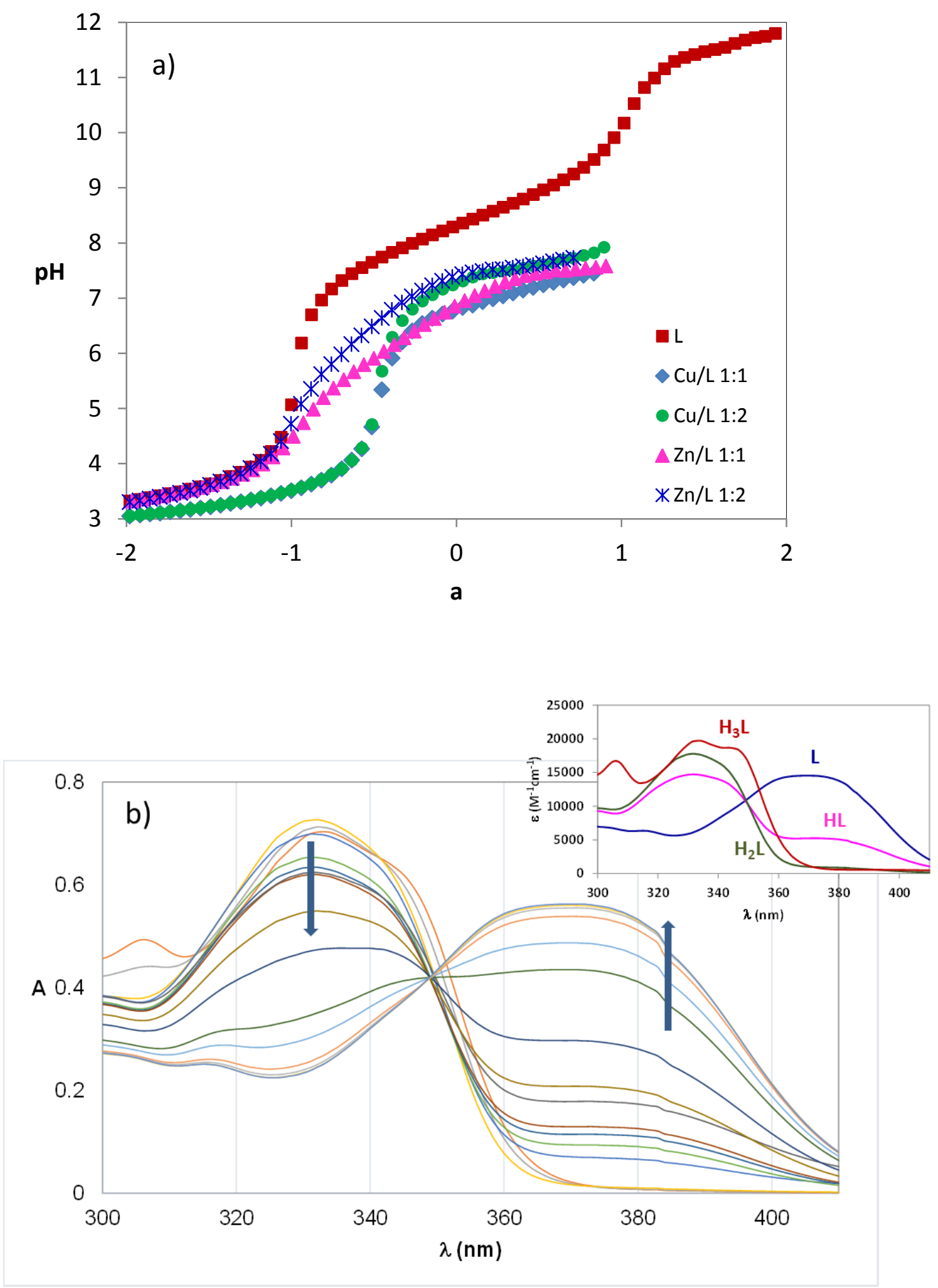

Figure 1 - a) Potenciometric titration curves of compound $1\left(C_{\mathrm{L}}=6.7 \times 10^{-4} \mathrm{M}\right)$ in $50 \%$ w/w DMSO/water; b) Absorption spectra of $1\left(2.56<\mathrm{pH}<11.53, C_{\mathrm{L}}=4 \times 10^{-5} \mathrm{M}\right)$ in $50 \% \mathrm{w} / \mathrm{w} \mathrm{DMSO} /$ water and outset containing the individual calculated spectra by PSEQUAD [10]. 
Table 1 - Stepwise protonation constants of compound $\mathbf{1}$ and compound 2 for comparison purpose, as well as global formation constants ${ }^{\mathrm{a}}$ for their $\mathrm{Cu}(\mathrm{II})$ and $\mathrm{Zn}(\mathrm{II})$ ) complexes ( $T$ $\left.=25.0 \pm 0.1{ }^{\circ} \mathrm{C}, I=0.1 \mathrm{M} \mathrm{KCl}, 50 \% \mathrm{w} / \mathrm{w} \mathrm{DMSO} / \mathrm{water}\right)$ and $\mathrm{pM}^{\mathrm{b}}$ values.

\begin{tabular}{|c|c|c|c|c|}
\hline Compound & $\mathrm{M}_{\mathrm{m}} \mathrm{H}_{\mathrm{h}} \mathrm{L}_{\mathrm{l}}$ & $\log K_{\mathrm{i}}$ & $\log \beta_{\mathrm{Cu}_{\mathrm{m}} \mathrm{H}_{\mathrm{h}} \mathrm{L}_{1}}$ & $\log \beta_{\mathrm{Zn}_{\mathrm{m}} \mathrm{H}_{\mathrm{h}} \mathrm{L}_{1}}$ \\
\hline 1 & $\begin{array}{l}(011) \\
(021) \\
(031) \\
(111) \\
(101) \\
(1-11) \\
(122) \\
(102) \\
(1-12) \\
\mathrm{pM}\end{array}$ & $\begin{array}{l}8.98(2)^{\mathrm{c}} \\
9.00(1)^{\mathrm{d}} \\
7.78(4)^{\mathrm{c}} \\
7.11(3)^{\mathrm{d}} \\
2.86(5)^{\mathrm{c}} \\
2.38(8)^{\mathrm{d}}\end{array}$ & $\begin{array}{c}18.96(8)^{\mathrm{c}} \\
18.864(6)^{\mathrm{d}} \\
11.71(7)^{\mathrm{c}} \\
13.08(2)^{\mathrm{d}} \\
4.44(4)^{\mathrm{c}} \\
5.12(2)^{\mathrm{d}} \\
37.27(5)^{\mathrm{c}} \\
- \\
22.18(9)^{\mathrm{c}} \\
19.18(9)^{\mathrm{d}} \\
14.64(6)^{\mathrm{c}} \\
- \\
14.3^{\mathrm{c}} \\
13.9^{\mathrm{d}}\end{array}$ & $\begin{array}{c}26.51(9)^{\mathrm{c}} \\
- \\
3.77(8)^{\mathrm{c}} \\
6.4^{\mathrm{c}}\end{array}$ \\
\hline $2^{\mathrm{e}}$ & $\begin{array}{l}(011) \\
(021) \\
(031) \\
(111) \\
(122) \\
(102) \\
(1-12) \\
\text { pM }\end{array}$ & $\begin{array}{c}8.671(1) \\
7.39(1) \\
3.21(1)\end{array}$ & $\begin{array}{c}16.43(4) \\
32.13(4) \\
17.91(4) \\
8.20(6) \\
10.7\end{array}$ & $\begin{array}{c}13.13(3) \\
25.24(8) \\
9.94(8) \\
- \\
6.3\end{array}$ \\
\hline
\end{tabular}

Compound 1 was isolated in its neutral mono-protonated form (HL, $a=0$ in Fig. 1a)) after the synthetic procedure, although the fully protonated species corresponds to $\mathrm{H}_{3} \mathrm{~L}^{2+}$. The three protonation constants contained in Table $\mathbf{1}$ for compound $\mathbf{1}$ are in accordance, as expected, to those previously obtained for compound $\mathbf{2}$ and correspond to the protonation of the phenolic oxygen of the BIM moiety $\left(\log K_{1}\right)$, then the $N$-piperidine nitrogen atom $\left(\log K_{2}\right)$ and finally the imidazole nitrogen $\mathrm{N}(3)$ of the BIM portion $(\log$ 
$K_{3}$ ) [18]. The values obtained by both experimental techniques (potentiometry and UVvis spectrophotometry) are quite similar for $\log K_{1}$ values but present some discrepancies for $\log K_{\mathrm{i}}(\mathrm{i}=2,3)$, probably due to the fact that the UV-vis spectrophotometric titrations have higher experimental errors also since they are not performed in automated manner as the potentiometric ones.

Taking into consideration the outset in Fig. 1b), enclosing the calculated spectra by PSEQUAD of the different protonated species for compound 1, it is possible to see that: the fully protonated species $\left(\mathrm{H}_{3} \mathrm{~L}^{2+}\right)$ has three absorption maxima at 306,334 and $343 \mathrm{~nm}$; the absorption at $332 \mathrm{~nm}$ correspond to both di- and mono-protonated species $\left(\mathrm{H}_{2} \mathrm{~L}^{+}\right.$and $\mathrm{HL}$ ); the mono-protonated HL and the deprotonated $\mathrm{L}^{-}$species have a large absorption band with maximum at ca $373 \mathrm{~nm}$. Moreover, at $\mathrm{pH} 7.4$ and considering $C_{\mathrm{L}}=10^{-5} \mathrm{M}$, as an attempt to mimic the physiological conditions, the predominant species is: for compound $1, \mathrm{H}_{2} \mathrm{~L}^{+}(70 \%)$ with a contribution of $29 \%$ of the neutral HL species; for compound 2, the neutral HL (50\%) and $48 \%$ of $\mathrm{H}_{2} \mathrm{~L}^{+}$. Even though the lipo-hydrophilic character is not only determined by the molecular charge but also by the ability to establish solute-solvent interactions, the existence of the neutral HL species in significant concentrations (ca 29-50\%) explains the need of using a 50\% w/w DMSO/water medium in the solution studies. In fact, in particular compound $\mathbf{2}$ showed to be insoluble for inferior \% of DMSO content in the DMSO/water mixtures.

\subsection{Metal chelation}

\subsubsection{Solution equilibrium studies}

The existence of a BIM moiety in the structure of potential anti-neurodegenerative drugs was already proven to endow the compounds with capacity for hitting several AD targets, such as biometal chelation, eventual dual AChE interaction, as well as self- and $\mathrm{Cu}-$ mediated $A \beta$ aggregation [18-20]. Concerning metal chelation, the BIM unity is a bidentate moiety and its $(N, O)$ coordination mode implicates a good potential coordination towards hard-soft metal ions. The study of the metal chelating properties of compound $\mathbf{1}$, a positional isomer of the already studied compound $\mathbf{2}$, containing the BIM unit ortho-attached to the benzylpiperazinic moiety, will also show the possibility of formation of a $(N, O, O)$ metal coordination type involving both the BIM moiety and the adjacent carbonyl oxygen atom.

The chelating ability of compound $\mathbf{1}$ was studied by using the same experimental techniques (potentiometry, UV-vis spectrophotometry) and experimental medium used 
for the titration of the ligand alone $(50 \% \mathrm{w} / \mathrm{w} \mathrm{DMSO} /$ water $)$. In the following calculations for the $1: 1$ and $1: 2 \mathrm{M} / \mathrm{L}$ systems $(\mathrm{M}=\mathrm{Cu}, \mathrm{Zn})$, the $\log K_{i}$ values previously obtained by each experimental method will be used in the complexation studies performed by the same methodology. Fig. 1a) evidences an alteration in the deprotonation profile of the ligand titration curve due to the presence of the metal ion since the curves for the $\mathrm{M}(\mathrm{II}) / \mathrm{L}$ systems lye well below that of the ligand for $a>-2(\mathrm{M}=\mathrm{Cu})$ or $a>-1(\mathrm{M}=\mathrm{Zn})$, thus supporting the formation of metal complexes with the deprotonated (L') and monoprotonated (HL) forms of the ligand with comparative stability order $\mathrm{Cu}>\mathrm{Zn}$. The potentiometric curves seem to be in accordance with a $(N, O)$ coordination mode, involving the BIM moiety of compound 1, as already found for other BIM derivatives $[18,21]$. Table 1 contains the equilibrium models obtained from the fitting analysis of the potentiometric curves $(\mathrm{M}=\mathrm{Cu}, \mathrm{Zn})$ and the $\mathrm{UV}$-vis spectral data $(\mathrm{M}=\mathrm{Cu})$.

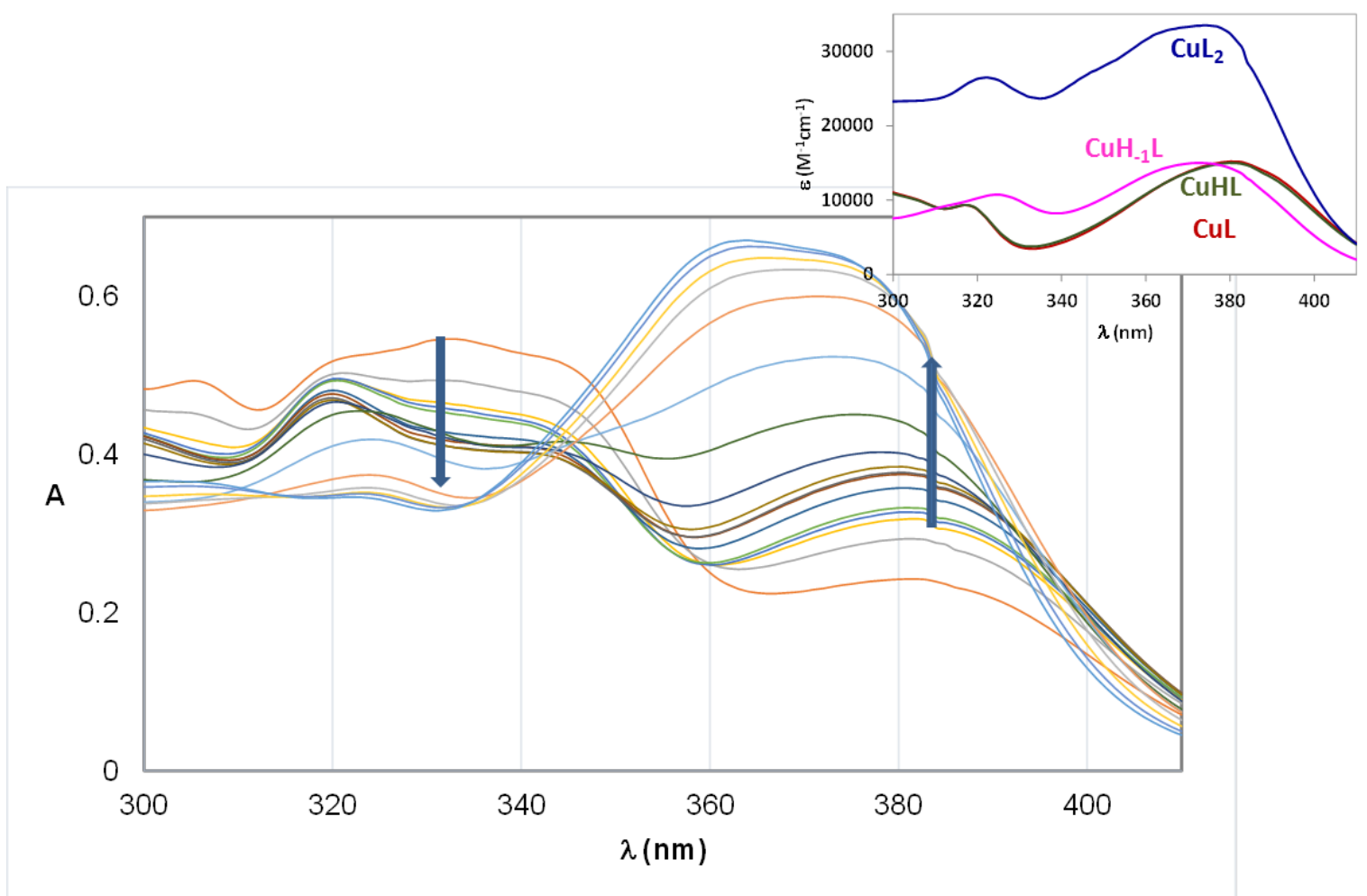

Figure 2 - Spectrophotometric absorption spectra of the 1:2 $\mathrm{Cu}^{2+} / 1$ system $(2.58<\mathrm{pH}<$ $\left.11.51, C_{\mathrm{L}}=4.0 \times 10^{-5} \mathrm{M}\right)$ in $50 \% \mathrm{w} / \mathrm{w} \mathrm{DMSO} /$ water and outset and outset containing the individual calculated spectra by PSEQUAD [10].

In the obtained metal complex models, MHL and $\mathrm{MH}_{2} \mathrm{~L}_{2}$ (not found from 1:2 $\mathrm{Cu}^{2+} / 1$ spectral data) correspond to species with the ligand containing one protonated nitrogen 
atom at the piperidine moiety, while $\mathrm{ML}$ and $\mathrm{ML}_{2}$ correspond to complexes involving the completely deprotonated form of the ligand; $\mathrm{MH}_{-1} \mathrm{~L}$ and $\mathrm{MH}_{-1} \mathrm{~L}_{2}$ (not found from 1:2 $\mathrm{Cu}^{2+} / \mathbf{1}$ spectral data) are mixed ligand-hydroxo metal complexes. The models obtained for $\mathrm{Cu}^{2+} / \mathbf{1}$ system from potentiometric and spectrophotometric data (see Table 1) are not identical but quite similar.

The outset of Figure 2 evidences that the calculated spectra $\left(\lambda \max \left(\varepsilon, M^{-1} \mathrm{~cm}^{-1}\right)\right.$ at $317 \mathrm{~nm}$ $\left(9.3 \times 10^{3}\right)$ and $\left.380 \mathrm{~nm}\left(1.5 \times 10^{4}\right)\right)$ for both $\mathrm{CuHL}$ and $\mathrm{CuL}$ complexes are equal, resulting from the fact that the coordination core is exactly the same and so the piperidinic nitrogen does not contribute to the copper coordination as already found for compound 2 [18]; the intensity of the calculated spectrum rises for the $\mathrm{CuL}_{2}$ species, that displays $\lambda_{\max }\left(\varepsilon, \mathrm{M}^{-}\right.$ $\left.{ }^{1} \mathrm{~cm}^{-1}\right)$ values corresponding to a shoulder at $361 \mathrm{~nm}\left(3.2 \times 10^{4}\right)$ and a band at $374(3.4 \times$ $\left.10^{4}\right) \mathrm{nm}$. As expected, to the $\mathrm{CuH}_{-1} \mathrm{~L}$ species corresponds also a more intense spectrum with a blue shift of the bands relatively to $\mathrm{CuHL} / \mathrm{CuL}\left(372 \mathrm{~nm}\left(1.5 \times 10^{4}\right)\right)$, corresponding to the formation of a complex that has an additional coordination site occupied by an apical water molecule.

Comparing, the spectral data of the $\mathrm{Cu}^{2+} / 1$ and $\mathrm{Cu}^{2+} / 2$ systems [18], the most striking difference relates to the spectra of the CuHL species, with $\lambda_{\max }$ at 320,335 and $365 \mathrm{~nm}$. The inexistence, in this last case, of a band at $380 \mathrm{~nm}$ may point towards the formation of a MHL complex with a coordination core more strained in the case of compound $\mathbf{1}$ than for compound 2 .

Figure 3 shows the species distribution curves for the 1:2 $\mathrm{Cu}(\mathrm{II}) / \mathbf{1}$ and $\mathrm{Zn}(\mathrm{II}) / \mathbf{1}$ systems by using the potentiometric determined model at the used experimental conditions.

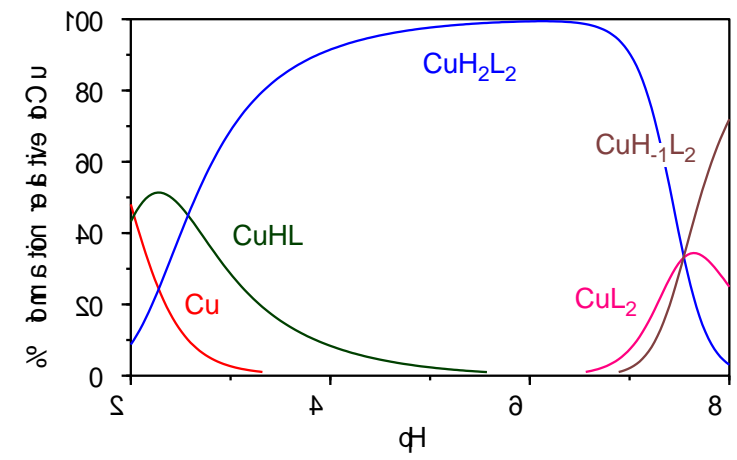

a)

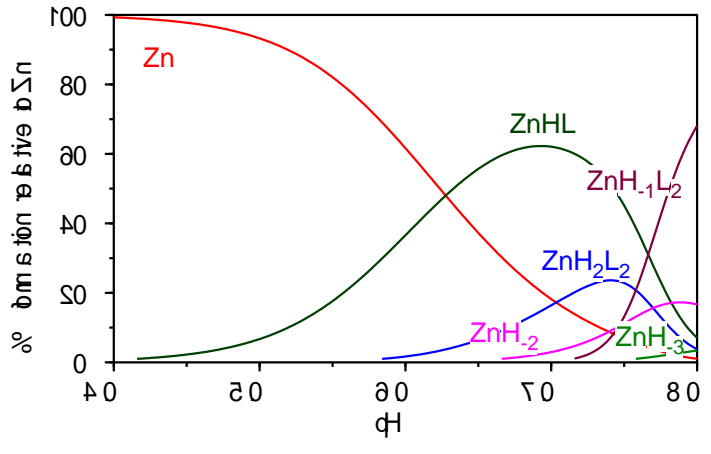

b) 
Figure 3 - Species distribution curves for the 1:2 M/1 systems: a) $\mathrm{M}=\mathrm{Cu}$; b $) \mathrm{M}=\mathrm{Zn}\left(C_{\mathbf{L}}\right.$ $\left.=6.7 \times 10^{-4} \mathrm{M}\right)$.

Comparison of the metal chelating capacity of compound $\mathbf{1}$ with that of the already studied analogous compound 2 (see Table1) reveals that the $\mathrm{pM}$ values (at $\mathrm{pH} 7.4, C_{\mathrm{L}} / C_{\mathrm{M}}$ $=10, C_{\mathrm{M}}=10^{-6} \mathrm{M}$ ) are analogous for zinc but higher for copper, which may point towards the possibility of compound $\mathbf{1}$ having a different copper coordination core, eventually including the adjacent carbonyl oxygen atom, with correspondingly higher stability of the copper complex with 1 . In fact, previous studies on the copper chelation ability of 8 hydroxyquinoline (HQ, $\mathrm{pCu}=13.2$ in $60 \% \mathrm{w} / \mathrm{w} \mathrm{DMSO} /$ water) [22], a commonly known stong chelator, reveals that compound 1 presents a slightly higher $\mathrm{Cu}^{2+}$ chelating capacity than HQ while compound $\mathbf{2}$ shows a small reduction.

To further examine the proposed complexation models, ESI-MS data was also obtained from solutions of $\mathrm{M} / \mathbf{1}(\mathrm{M}=\mathrm{Cu}, \mathrm{Zn})$, in $50 \% \mathrm{w} / \mathrm{w} \mathrm{DMSO} / \mathrm{H}_{2} \mathrm{O}$ and $1: 1$ and 1:2 M/L stoichiometric conditions, at specific $\mathrm{pH}$ values. The obtained spectra confirmed the existence of 1:1 and 1:2 metal complexes (see Table 2 and Figure 4). The ESI-MS analysis of a solution of the $1: 1 \mathrm{Cu}^{2+} / 1$ system, at $\mathrm{pH} 4.28$ and in the negative mode, showed a group of peaks at m/z 571/573, suggesting a characteristic isotopic distribution of a $\left[\mathrm{Cu}(\mathrm{L}-\mathrm{H}) \mathrm{Cl}_{2}\right]^{-}$species. However, due to the lower intensity of the signal, a clear fit with a calculated isotopic distribution for $\left[\left(\mathrm{C}_{27} \mathrm{H}_{27} \mathrm{~N}_{4} \mathrm{O}_{2}\right) \mathrm{CuCl}_{2}\right]^{-}$was not achieved.

Table 2 - ESI-MS ions for the $\mathrm{Cu}^{2+}$ and $\mathrm{Zn}^{2+}$ complexes of compound 1 in $50 \% \mathrm{w} / \mathrm{w}$ $\mathrm{DMSO} / \mathrm{H}_{2} \mathrm{O}\left(1: 2 \mathrm{M} / \mathrm{L}, C_{\mathrm{L}}=2.25 \times 10^{-4} \mathrm{M}\right)$.

\begin{tabular}{|c|c|c|c|}
\hline Species & $\mathrm{pH}$ & $\begin{array}{c}\mathrm{M}=\mathrm{Cu} \\
(\mathrm{m} / \mathrm{z})\end{array}$ & $\begin{array}{c}\mathrm{M}=\mathrm{Zn} \\
(\mathrm{m} / \mathrm{z})\end{array}$ \\
\hline$\left[\mathrm{M}(\mathrm{L}-\mathrm{H}) \mathrm{Cl}_{2}\right]^{-}$ & 7.01 & - & $573.2 / 575.2 / 577.1$ \\
{$[\mathrm{M}(\mathrm{L}-\mathrm{H}) \mathrm{L}]^{+}$} & 6.42 & $942.2 / 944.2$ & - \\
{$[\mathrm{M}(\mathrm{L}-\mathrm{H}) \mathrm{L}]^{+}$} & 8.39 & - & $943.2 / 945.2$ \\
\hline
\end{tabular}

L represents the neutral mono-protonated form of compound 1 

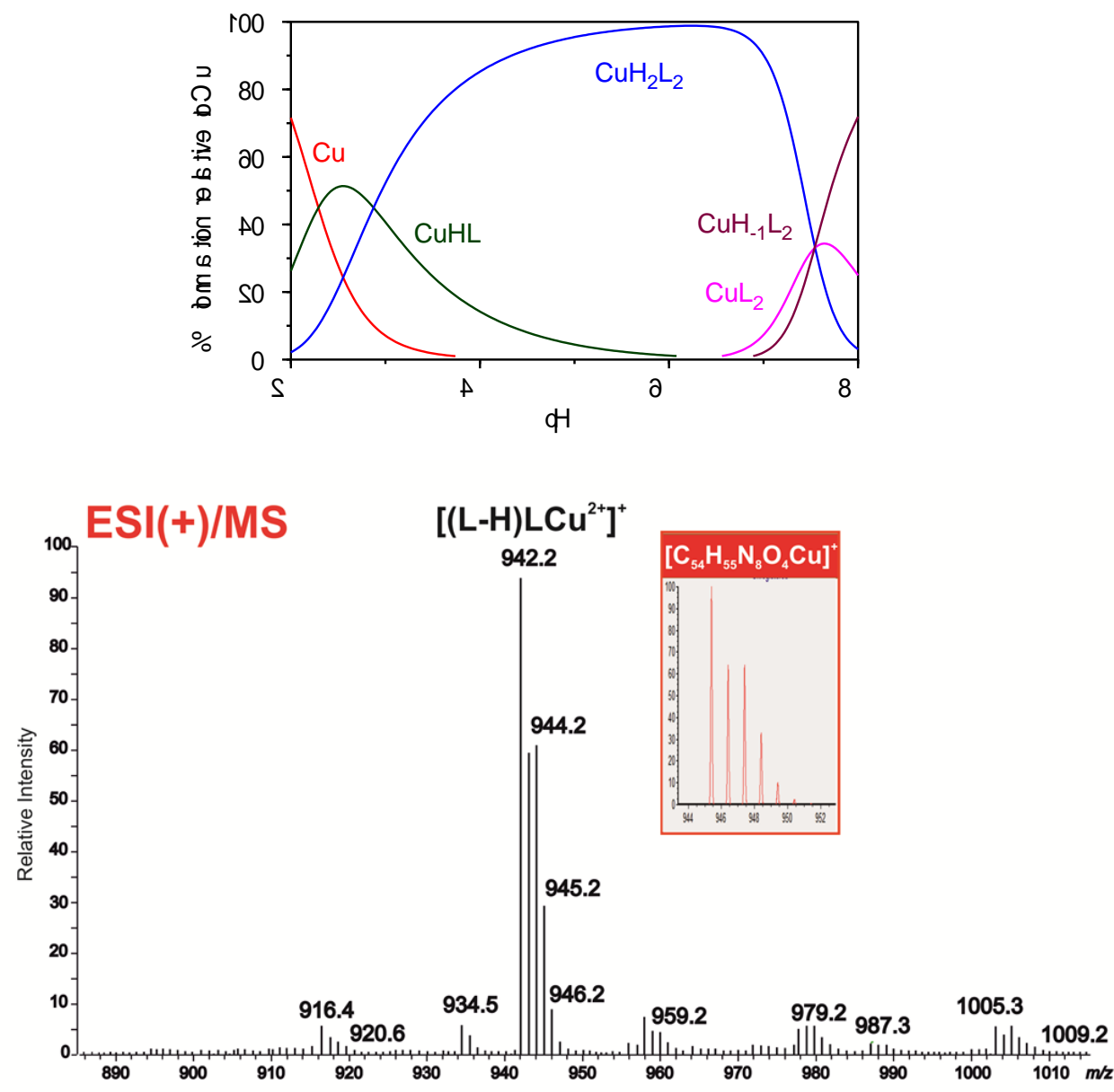

a) 


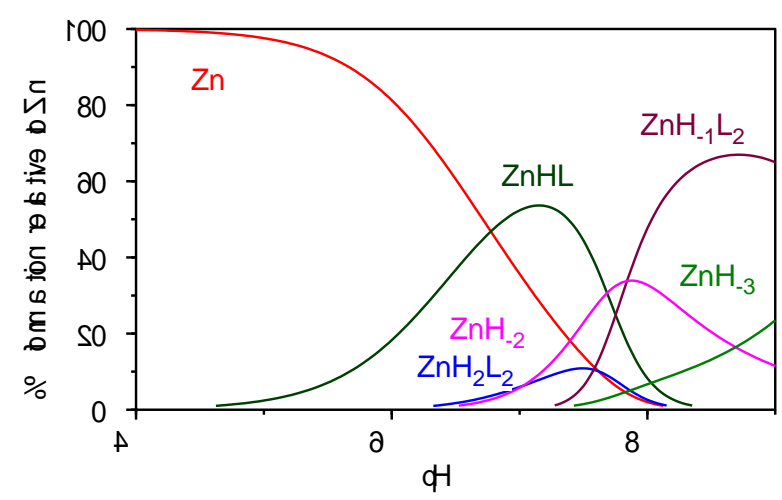

\section{ESI(-)/MS}

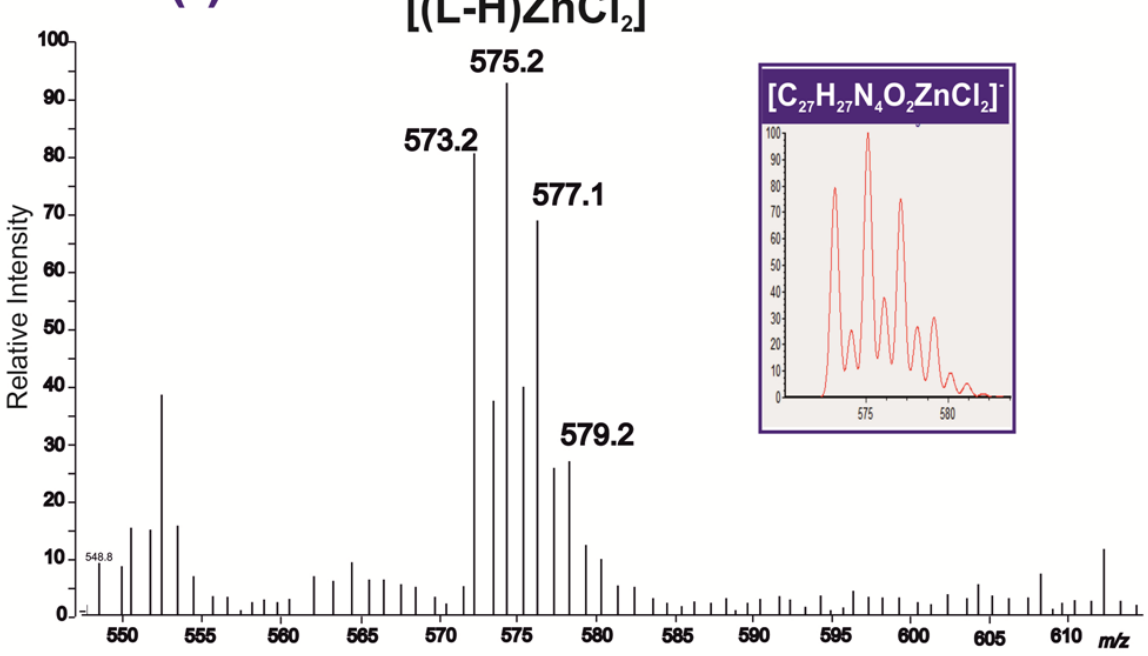

b)

Figure 4 - a) Expanded $\operatorname{ESI}(+)$ mass spectrum for the $\mathrm{Cu}(\mathrm{II}) / \mathbf{1}$ system $\left(C_{\mathrm{L}} / C_{\mathrm{Cu}}=2, C_{\mathrm{L}}=\right.$ $\left.2.25 \times 10^{-4} \mathrm{M}, \mathrm{pH}=6.42\right)$ and species distribution curves. The insert shows the theoretical isotopic pattern for $\left[\left(\mathrm{C}_{54} \mathrm{H}_{55} \mathrm{~N}_{8} \mathrm{O}_{4}\right) \mathrm{Cu}\right]^{+}$; b) Expanded ESI(-) mass spectrum for the $\mathrm{Zn}(\mathrm{II}) / \mathbf{1}$ system $\left(C_{\mathrm{L}} / C_{\mathrm{Zn}}=2, C_{\mathrm{L}}=2.25 \times 10^{-4} \mathrm{M}, \mathrm{pH}=7.01\right)$ and species distribution curves. The insert shows the theoretical isotopic pattern for $\left[\left(\mathrm{C}_{27} \mathrm{H}_{27} \mathrm{~N}_{4} \mathrm{O}_{2}\right) \mathrm{ZnCl}_{2}\right]$.

Finally, to analyze the copper coordination core of the complexes with compounds $\mathbf{1}$ and 2, EPR spectra of these copper systems were obtained, at room temperature and in frozen solution together with the calculated EPR spectra of the component species (see Figure 5). The solution EPR spectra for the studied systems could be mainly described by free copper, $\mathrm{CuLH}$ and $\mathrm{CuL}_{2} \mathrm{H}_{2}$, as well as the ratio of the species agreed well with the distribution curves at the selected $\mathrm{pH}$ working values. For the systems with compound $\mathbf{1}$ 
(1:1) in RT solution and $\mathbf{2}$ in frozen solution, only the CuLH complex or the free copper and $\mathrm{CuLH}$ could be detected, respectively. In those cases, the 1:2 $\mathrm{Cu} / \mathrm{L}$ complex was not formed. Nevertheless, for compound $\mathbf{1}$, the frozen solution sample recorded at 1:1 ratio showed a dimer species $\left(\mathrm{Cu}_{2} \mathrm{~L}_{2} \mathrm{H}_{2}\right)$, besides $\mathrm{CuLH}$, which frequently forms for aromatic flat ligands by the off-centered parallel stacking interaction of two mono-complexes arranged above each other. The frozen solution spectra of the $\mathrm{CuLH}$ and $\mathrm{CuL}_{2} \mathrm{H}_{2}$ complexes show well resolved nitrogen splitting, and could be simulated with one nitrogen for $\mathrm{CuLH}$ and two nitrogens for $\mathrm{CuL}_{2} \mathrm{H}_{2}$, in accordance with the involvement of one or to BIM chelating cores. The obtained EPR data are collected in Table 3.

The comparison of the EPR data for the CuLH complexes of compounds $\mathbf{1}$ and $\mathbf{2}$ allows concluding that the isotropic and anisotropic $g$ values reflect higher ligand field for compound $\mathbf{1}$ than for compound $\mathbf{2}$, since the galues are lower for compound $\mathbf{1}$. This result supports the already suggested $(N, O, O)$ tridentate coordination mode for compound 1, with the involvement of the adjacent carbonyl oxygen atom. For the 1:2 copper complex of compound $\mathbf{1}$ it is probable that the second ligand coordinates equatorially with its imidazole nitrogen and axially with the phenolate oxygen atom. This coordination change agrees with the facts that $g_{z}$ value decreases only 0.01 , comparing with the same value of the 1:1 complex, and the $\mathrm{A}_{\mathrm{z}}$ value also declines evidencing an axial coordination with small rhombic distortion.
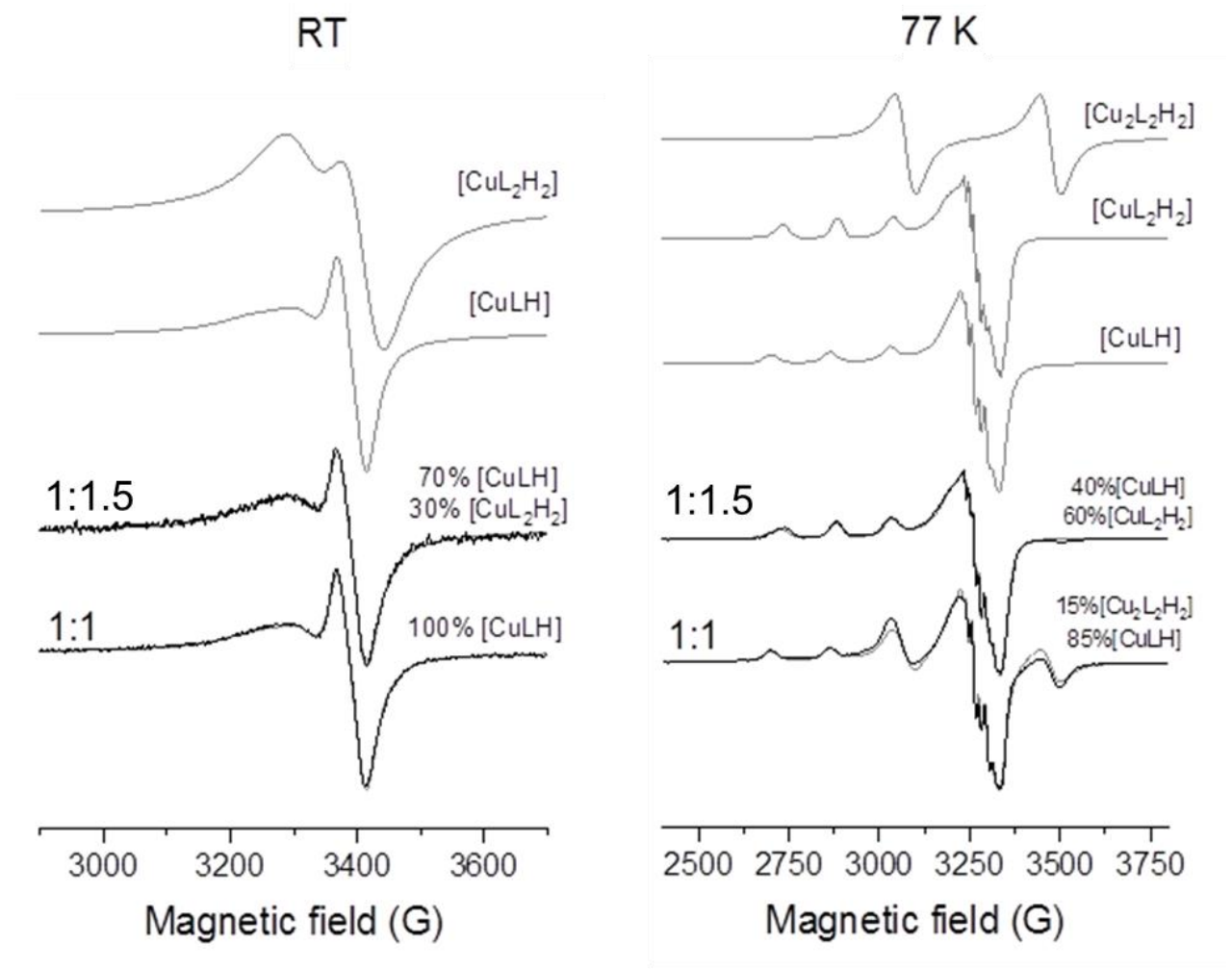
a)
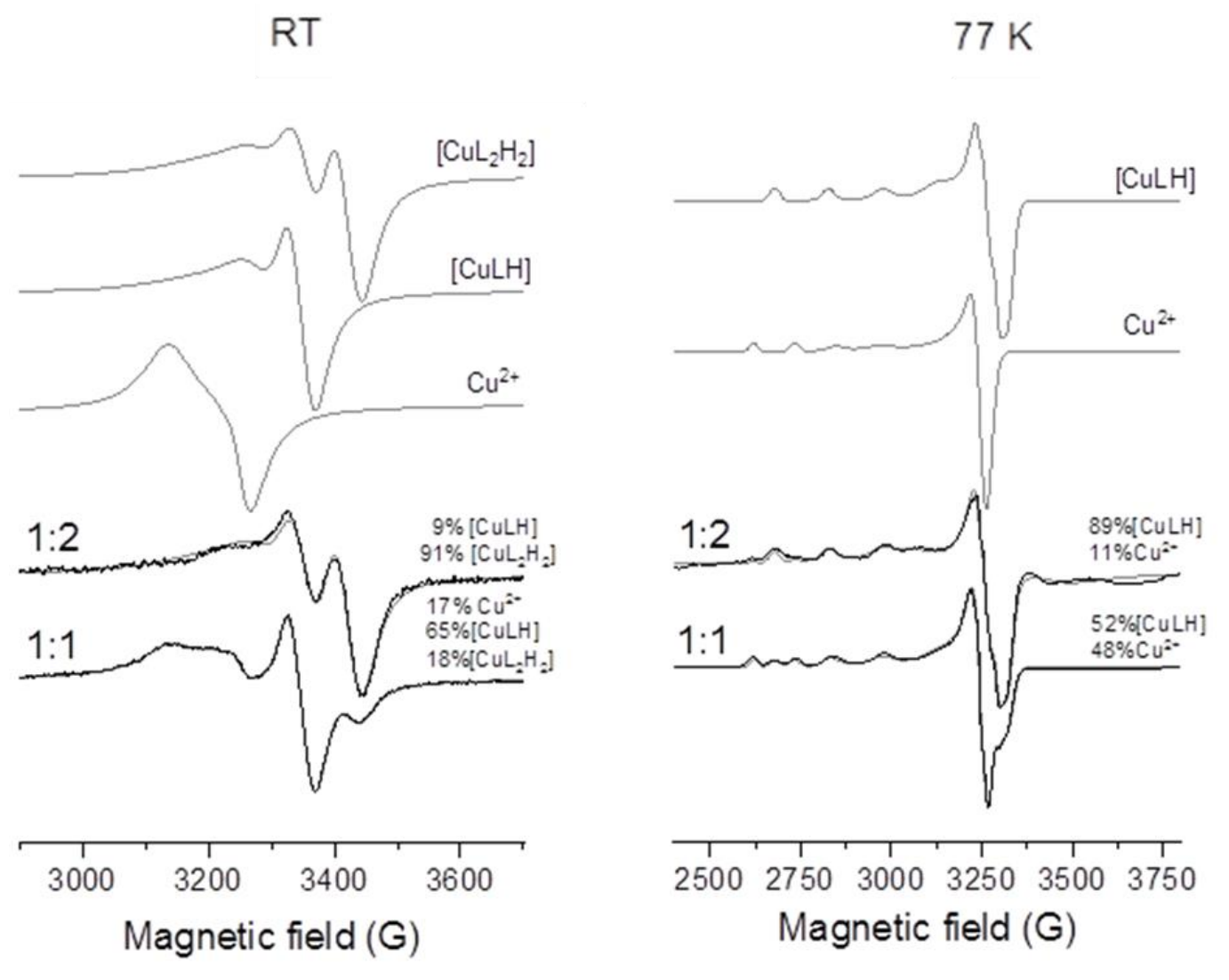

b)

Figure 5 - Measured (black) and calculated (grey) EPR spectra obtained for a) $\mathrm{Cu}^{2+} / 1$ 1:1 $(\mathrm{pH}=6.75)$ and $1: 1.5(\mathrm{pH}=6.91) ; \mathrm{b}) \mathrm{Cu}^{2+} / 21: 1(\mathrm{pH}=5.46)$ and $1: 2(\mathrm{pH}=5.72)$ systems at room temperature (left) and in frozen solution (right).

Table 3 - Isotropic and anisotropic EPR parameters obtained for the $\mathrm{Cu}^{2+}$ complexes with compounds $\mathbf{1}$ and $\mathbf{2}^{\mathrm{a}}$

\begin{tabular}{|c|c|c|c|c|c|c|c|c|c|c|c|c|c|}
\hline Compound/species & $g_{0}$ & $\mathrm{~A}_{0} / \mathrm{G}$ & $a_{0}{ }^{N} / G$ & $\mathrm{~g}_{0, \text { calc }^{b}}{ }^{\mathrm{b}}$ & $g_{x}$ & $\mathrm{~g}_{\mathrm{y}}$ & $\mathrm{g}_{\mathrm{z}}$ & $A_{x} / G$ & $\mathrm{~A}_{\mathrm{y}} / \mathrm{G}$ & $\mathrm{A}_{2} / \mathrm{G}$ & $a_{x}{ }^{N} / G$ & $a_{y}{ }^{N} / G$ & $\mathrm{a}_{\mathrm{z}}^{\mathrm{N}} / \mathrm{G}$ \\
\hline \multicolumn{14}{|l|}{1} \\
\hline $\mathrm{CuLH}$ & 2.123 & 54.9 & 14.5 & 2.134 & 2.058 & 2.057 & 2.287 & 15.8 & 16.2 & 161.4 & 14.2 & 17.3 & 4.8 \\
\hline \multirow{2}{*}{$\mathrm{CuL}_{2} \mathrm{H}_{2}$} & 2.120 & 66.0 & 14.5 & 2.127 & 2.048 & 2.059 & 2.275 & 20.7 & 3.9 & 149.0 & 14.5 & 15.0 & 9.9 \\
\hline & & & & & & & & & & & 10.1 & 11.9 & 10.3 \\
\hline $\mathrm{Cu}_{2} \mathrm{~L}_{2} \mathrm{H}_{2}{ }^{\mathrm{c}}$ & 2.066 & & & & & & & & & & & & \\
\hline \multicolumn{14}{|l|}{2} \\
\hline $\mathrm{Cu}$ & 2.194 & 31.6 & & 2.196 & 2.086 & & 2.417 & 6.9 & 110 & & & & \\
\hline CuLH & 2.156 & 59.6 & 13.6 & 2.148 & 2.060 & & 2.324 & 15.2 & & 145 & 14.1 & 14.1 & 10.0 \\
\hline $\mathrm{CuL}_{2} \mathrm{H}_{2}$ & 2.111 & 61.3 & 10.8 & & & & & & & & & & \\
\hline
\end{tabular}

So, the spectral data collected, namely EPR information, and the callculated equilibrium models obtained for compound $\mathbf{1}$ point towards a chelating core composed by the $\mathrm{N}(3)$ 
imidazole and O-phenol atoms of the ligands, excluding the hypothesis of metal coordination through the distant nitrogen atom of the piperidine [18], but eventually including the adjacent carbonyl oxygen atom in the case of the copper complexes.

\subsubsection{Molecular modeling of the copper complexes}

In the absence of X-ray structures, a molecular modelling study was accomplished aimed at providing some further insight into the 1:1 copper complex structures with compounds 1 and 2. In that way, a tridentate $(N, O, O)$ coordination mode was considered for compound 1, involving one coordinated water molecule, while a bidentate $(N, O)$ coordination type was adopted for compound $\mathbf{2}$ and two coordinated water molecules were included in the chelating core. These studies were carried out with full geometry optimization of the $\mathrm{Cu}^{2+}$ complexes by quantum mechanical calculations based on DFT methods [23] included in the Gaussian 03 program software [12] with the B3PW91 functional [24]. Geometry optimizations were obtained by using 3-21G basis set [25] for all elements, first, and afterwards re-optimized using 6-31G** [26] for the main group elements and the Stuttgart-Dresden pseudopotential and associated basis set for $\mathrm{Cu}$ (SDD [27]). No symmetry constrains were enforced during geometry optimizations. The calculations were performed as well for one water molecule by using the B3PW91 functional, first with the $3-21 \mathrm{G}$ basis set and subsequently re-optimized via $6-31 \mathrm{G} * *$ basis set.

The energy-minimized structures of the copper complexes present a distorted tetrahedral square planar four-coordinate configuration for $\mathbf{1}$ while for $\mathbf{2}$ corresponds a distorted tetrahedral geometry (see Figure 6). 

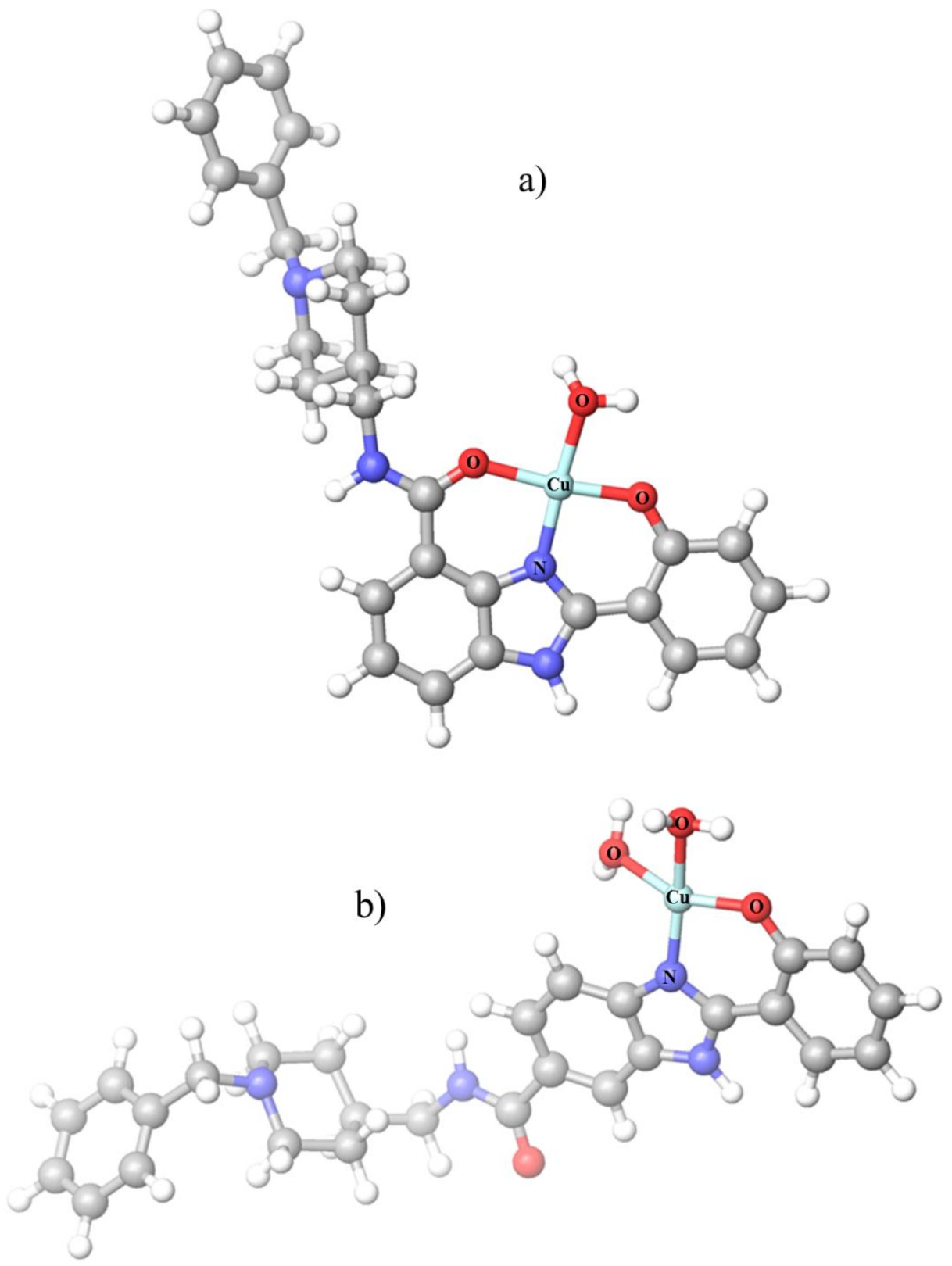

Figure 6 - DFT-minimized structures of 1:1 copper complexes with compound a) 1 and b) 2. Coloring of atoms: $\mathrm{Cu}$ light blue, $\mathrm{N}$ blue, $\mathrm{O}$ red, $\mathrm{C}$ grey and $\mathrm{H}$ white.

In the obtained modeling simulations, some identical coordination bond distances can be found between the two structures for $\mathrm{Cu}-\mathrm{H}_{2} \mathrm{O}(2.02-2.05 \AA)$ and $\mathrm{Cu}-O$-phenol (1.86-1.88 $\AA$ ), while the $\mathrm{Cu}-\mathrm{N}$ distance increases somehow from the copper complex with $\mathbf{1}$ (1.88 $\AA$ ) to that with 2 (1.91 $\AA$ ), probably due to the stronger tridentate coordination established in the case of complex with $\mathbf{1}$, that also involves the adjacent $O$-carbonyl atom (distance $\mathrm{Cu}-O$-carbonyl $1.96 \AA$ ). In the case of the complex with compound $\mathbf{1}$, the distortion in relation to a regular square planar geometry is well demonstrated by the coordination 
bond angles (83.6-93. $0^{\circ}$ ) and the almost planar geometry as showed by the bond angles of $O$-phenol-Cu-O-carbonyl $\left(173.1^{0}\right)$ and $\mathrm{N}-\mathrm{Cu}$-water $\left(174.8^{0}\right)$. On the other hand, the copper coordination with compound $\mathbf{2}$ also exhibits a strong distortion from a tetrahedral geometry, with coordination bond angles ranging from 82.4 to $99.7^{0}$.

Since these two complexes do not have exactly the same number of atoms, comparison of complex stability was based on the determination of the free energy difference $(\Delta \mathrm{G}=$ $25.6 \mathrm{Kcal} / \mathrm{mol}$ ) between $\mathrm{Cu}-\mathbf{1}$ complex plus one water molecule and $\mathrm{Cu}-\mathbf{2}$ molecule. Therefore, the calculations show that the copper complex with compound $\mathbf{1}$ is more stable than that with compound $\mathbf{2}$, which is according to the previously presented solution studies.

\subsection{Biological activity}

\subsubsection{AChE and $A \beta$ aggregation inhbitory activity}

Compound 1 under study was assayed for AChE inhibition through a reported method [29] and proved to have a quite good activity $\left(\mathrm{IC}_{50}=9 \mu \mathrm{M}\right)$, analogous to that of compound 2 (see Table 4), which is supported by the docking simulations. Actually, previous studies already revealed that compounds with BIM motif have good AChE inhibitory capacity, in low micromolar range [18-20], although presenting higher values than the parent compound DNP. Even so, this last fact does not abolish the purpose of the suggested drug design since in multifactorial diseases the advantages of using a multitarget drug can overcome the disadvantage of losing some specific property corresponding to a unique target drug.

Table 4 - Biological properties of compounds 1 and 2: inhibition of AChE (Electric eel), self-mediated and $\mathrm{Cu}$-induced $\mathrm{A} \beta_{1-42}$ aggregation as well as some predicted pharmacokinetic parameters.

\begin{tabular}{|c|c|c|c|c|c|}
\hline Compound & $\begin{array}{c}\text { EeAChE } \\
\left(\mathrm{IC}_{50}, \mu \mathrm{M}\right)^{\mathrm{a}}\end{array}$ & $\begin{array}{c}\mathrm{A} \beta \text { aggreg }(\%)^{\mathrm{b}} \\
\text { self-med }\end{array}$ & $\begin{array}{c}\mathrm{A} \beta \text { aggreg }(\%)^{\mathrm{b}} \\
\text { Cu-ind }\end{array}$ & $\log P^{\mathrm{c}, \mathrm{d}}$ & $\log \mathrm{BB}^{\mathrm{c}, \mathrm{e}}$ \\
\hline $\mathbf{1}$ & $9 \pm 1$ & 38.6 & 58.9 & 4.35 & -0.64 \\
\hline $\mathbf{2}$ & $4.2 \pm 0.8^{\mathrm{f}}$ & 48.8 & 69.0 & 4.39 & -0.73 \\
\hline $\mathrm{DNP}^{\mathrm{f}}$ & 0.026 & - & - & 4.43 & 0.13 \\
\hline
\end{tabular}

${ }^{a}$ mean \pm SEM (standard error of the mean) of 3 experiments for $50 \%$ inhibition of electric eel AChE (EeAChE); ${ }^{\mathrm{b}}$ Inhibiton of self- and $\mathrm{Cu}$-mediated $\mathrm{A} \beta_{1-42}$ aggregation by thioflavin-T fluorescence method; measurements in presence of inhibitor (40 $\mu \mathrm{M})$ 
for $40 \mu \mathrm{M} \mathrm{A} \beta_{1-42}$ and the values are mean of three independent measurements in duplicate (SEM < 10\%); ${ }^{\mathrm{c}}$ predicted values using QikProp program, v. 2.5, ref. [7]; ${ }^{\mathrm{d}}$ octanol/water partition coefficient; ${ }^{\mathrm{e}}$ brain/blood partition coefficient; ${ }^{\mathrm{f}}$ ref. [28]

The anti-amyloidogenic capacity of compound $\mathbf{1}$, in the absence and in the presence of copper, was evaluated based on the measurement of the fluorescence emission of Thioflavin T (ThT) associated to fibril binding [15,16]. Due to solubility problems of compound 1 in the phosphate buffer $(0.215 \mathrm{M}, \mathrm{pH} 8.0)$ working medium, the assays were accomplished in the presence of $40 \mu \mathrm{M}$ concentration of inhibitor, instead of $80 \mu \mathrm{M}$ $[18,20]$, and so the same procedure was adopted for compound $\mathbf{2}$ for comparison reasons (see Table 4). The obtained data show that both compounds induce a decrease on the ThT fluorescence associated with $\mathrm{A} \beta$ fibril binding. In fact, they inhibit the $\mathrm{A} \beta_{1-42}$ selfaggregation process with good capacity, slightly higher for the positional isomer $\mathbf{2}$ than for compound $\mathbf{1}$, probably due to conformational reasons in the ligand intercalation between the $\mathrm{A} \beta$ fibrils. In terms of the inhibition of $\mathrm{Cu}$-induced $\mathrm{A} \beta$ aggregation, the compounds induce an analogous increase (20.2-20.3\%) when comparing with their corresponding capacity for self-inhibition, in accordance with their good chelating capacity towards copper. Nevertheless, these chelators have conditional dissociation constants $\left(K^{\prime}{ }_{d}\right)$ for the copper complexes at $\mathrm{pH} 7.4$ of 254 picomolar $(\mathbf{1})$ and 34 nanomolar (2), these values being outside the proposed range $K^{\prime}{ }_{d}=1-10$ picomolar corresponding to chelators eventually able to retrieve copper from $\mathrm{A} \beta$ peptide $\left(K_{\mathrm{d}}^{\prime}=10\right.$ picomolar -100 nanomolar for $\mathrm{Cu}(\mathrm{A} \beta)$ complexes) [30]. In this way, there is no competition for copper between these $\mathrm{BIM}$ hybrids and $\mathrm{A} \beta$ peptide, the inhibition process being apparently mainly due to ligand intercalation between the $\beta$-sheets of $\mathrm{A} \beta$ fibrils.

In order to assess the potential of compound $\mathbf{1}$ as an eventual drug, some indicators of its pharmacokinetic profiles were calculated with QikProp program [7]. Parameters such as the lipo-hydrophilic character $(\log P)$, the ability to cross the blood-brain barrier $(\log B B)$, the ability to be absorbed through the intestinal tract to the blood (Caco-2 cell permeability), and the verification of Lipinski's rule of five, can give an idea of its druglikeness for oral administration as an anti-AD drug. Both the positional isomers have the same molecular weight (440.5) lower than 500 and present similar lipo-hydrophilic character and no violations of the Lipinski's rule, 's, although the slightly higher values for $\log P, \log \mathrm{BB}$ and caco permeability can be responsible for the slightly better CNS activity predicted for the isomer $\mathbf{1}$ as compared with $\mathbf{2}$. In summary, both positional 
isomers present good BBB permeability $(\log \mathrm{BB})$ and can be eligible as drug candidates for oral administration.

Table 5 - Pharmacokinetic properties as predicted in silico by software QikProp v.2.5[7].

\begin{tabular}{|c|c|c|c|c|c|c|}
\hline Comp. & $\begin{array}{c}\text { MW } \\
\text { (Da) }\end{array}$ & $\operatorname{clog} \boldsymbol{P}$ & $\log$ BB & $\begin{array}{c}\text { Caco-permeability } \\
\text { (nm/s) }\end{array}$ & CNS & $\begin{array}{c}\text { Violations of } \\
\text { Lipinski's rule }\end{array}$ \\
\hline $\mathbf{1}$ & 440.54 & 4.352 & -0.638 & 225 & $+/-$ & 0 \\
\hline $\mathbf{2}$ & 440.54 & 4.386 & -0.730 & 194 & - & 0 \\
\hline
\end{tabular}

\subsubsection{Cell viability and neuroprotection}

Using neuroblastoma SHSY-5Y cells the potential therapeutic effect of compound 1 was tested exposing these cells to A $\beta 1-42$ peptides. For this new compound 1 a dose-response curve was performed to select a nontoxic concentration in order to analyze the neuroprotective effect (Fig. S2). It was observed that A $\beta 1-42$ induced a decrease in cell viability and, interestingly, compound 1 completely prevented A $\beta 1-42$ cellular toxicity, as cells present relative viability values comparable to untreated cells (see Fig. 10). In opposition, cells treated with Fe/Ascorbate have a decrease in cell viability which compound 1 could not prevent. These results demonstrate that the ortho-positional isomer (1) has a higher neuroprotective role than the positional isomer 2 [17], and thus a higher specificity against $A \beta$-induced cell toxicity.

\section{Conclusions}

A new DNP-BIM hybrid (compound 1), with the BIM unit orthoattached to the benzylpiperazinic moiety, was synthesized and studied with the aim of evaluating the effect of the imposed structural modification over its physico-chemical and biological properties as potential anti-AD drug, in comparison with a previously developed positional isomer (compound 2). Compound 1 was found to have a higher chelating capacity towards $\mathrm{Cu} 2+(\mathrm{pCu}=14.3, \mathrm{pZn}=6.4, \mathrm{pH} 7.4, \mathrm{CL} / \mathrm{CM}=10, \mathrm{CM}=10-6 \mathrm{M})$ than compound $2(\mathrm{pCu}=10.7, \mathrm{pZn}=6.3)$, due to the 1-order increasing of denticity, that allows the formation of a $(\mathrm{N}, \mathrm{O}, \mathrm{O})$ coordination core for $\mathrm{Cu} 2+$, as proved by EPR and molecular modeling data of the copper complexes. Concerning the biological properties, both compounds present good AChE inhibition (low micromolar range), in accordance with the docking studies, and are moderate/good inhibitors of $\mathrm{A} \beta$ self- and $\mathrm{Cu}$-mediated aggregation. Since there is no competition for copper between these BIM hybrids and A $\beta$ 
peptide, the inhibition process appears to be mainly due to ligand intercalation between the $\beta$-sheets of $A \beta$ fibrils. Therefore, the herein compiled data allows concluding that afterapplying a structural change over the already studied compound 2, for the sake of increasing ligand denticity and thus improving the metal chelating capacity as well as the control/modulation of interconnected multiple pathological aspects of $\mathrm{AD}$, the obtained compound 1 presents quite analogous $\mathrm{AChE}$ and $\mathrm{A} \beta$ self- and $\mathrm{Cu}$-mediated aggregation inhibitory capacity, being also eligible as drug candidate for oral administration and with improved neuroprotective role against $A \beta$-induced cell toxicity.

\section{Abbreviations}

Acetylcholinesterase

$\mathrm{AChE}$

Acetylcholinesterase inhibitor

AChEI

Acetylthiocholine iodide

AChI

Alzheimer's disease

AD

Blood-brain

$\mathrm{BB}$

Hydroxyphenyl-benzimidazole

BIM

$\beta$-amyloid

A $\beta$

Cationic active site

CAS

Central nervous system

CNS

Charge transfer

CT

Donepezil

DNP

Donepezil based hydroxyphenyl-benzimidazole

DNP-BIM

Bis(3-carboxy-4-nitrophenyl) disulfide

DTNB

Electron paramagnetic resonance spectroscopy

EPR

Electrospray mass spectroscopy

ESI-MS

4-(2-Hydroxyethyl)-1-piperazineethanesulfonic acid

HEPES

1,1,1,3,3,3-Hexafluoro-2-propanol

HFIP 
3-(4,5-dimethylthiazol-2-yl)-2,5-diphenyltetrazolium bromide

Nuclear magnetic resonance spectroscopy

NMR

Peripheral anionic site

PAS

Thioflavin $\mathrm{T}$

ThT

Tris(hydroxymethyl)aminomethane

TRIS

Ultraviolet-visible spectrophotometry

UV-vis

\section{Acknowledgements}

The authors acknowledge the Portuguese Fundação para a Ciência e Tecnologia (FCT) for the projects UID/QUI/00100/2013, UID/QUI/00100/2019, and also the Portuguese NMR (IST-UL Center) and Mass Spectrometry Networks (Node IST-CTN) for providing access to their facilities, as well as to Dr. Conceição Oliveira for the collaboration in the mass spectra interpretation. The EPR studies were supported by the J. Bolyai Research Scholarship (N.V.M., BO/00109/17/7) of the Hungarian Academy of Sciences. We also thank the Erasmus fellowship (R.J.) from Europe Erasmus+ program.

\section{References}

[1] Alzheimer"s Association, Alzheimer's disease facts and figures, Alzheimers Dement. 15 (2019) (2019) 321-387.

[2] a) J.L. Cummings, T. Morstorf, K. Zhong, Alzheimers Res. Ther. 6 (2014) 37;

b) J. Marco-Contelles, ACS Chem. Neurosci. 10 (2019) 1127-1128.

[3] A. Rinaldi, EMBO Rep. 19 (2018) e46714.

[4] A.C. Tricco, H.M. Ashoor, C. Soobiah, et al., J. Am. Geriatr. Soc. 66 (2018) 170-178.

[5] R. Jakob-Roetne, H. Jacobsen, Angew. Chem. Int. Ed. 48 (2009) 3030-3059.

[6] S.A. James, I. Volitakis, P.A. Adlard, J.A. Duce, C.L. Masters, R.A. Cherny, A.I. Bush, Free Radic. Biol. Med. 52 (2012) 298-302.

[7] M.G. Savelieff, S. Lee, Y. Liu, M.H. Lim, ACS Chem. Biol. 8 (2013) 856-865.

[8] K.P. Kepp, R. Squitti, Coord. Chem. Rev. 397 (2019) 168-187.

[9] a) A.L. Hopkins, Nat. Chem. Biol. 4 (2008) 682-690;

b) A. Cavalli, M.L. Bolognesi, A. Minarini, M. Rosini, V. Tumiatti, M. Recanatini,

C. Melchiorre, J. Med. Chem. 51 (2008) 347-372.

[10] M.J. Oset-Gasque, J. Marco-Contelles, ACS Chem. Neurosci. 9 (2018) 401-403. 
[11] R.R. Ramsay, M.R. Popovic-Nikolic, K. Nikolic, E. Uliassi, M.L. Bolognesi, Clin. Transl. Med. 7 (2018) 1-14.

[12] M.A. Santos, K. Chand, S. Chaves, Fut. Med. Chem. 8 (2016) 2113-2142.

[13] M.A. Santos, K. Chand, S. Chaves, Coord. Chem. Rev. 327-328 (2016) 287-303.

[14] K. Chalupova, J. Korabeccny, M. Bartolini, B. Monti, D. Lamba, R. Caliandro,

A. Pesares, X. Brazzolotto, A.-J. Gastellier, F. Nachon, J. Pejchal, M. Jarosova,

D. Jun, M. Hrabinova, R. Dolezal, J. Karasova, M. Mzik, Z. Kristofikova, J. Misik,

L. Muckova, P. Jost, O. Soukup, M. Benkova, V. Setnicka, L. Habartova,

M. Chvojkova, L. Kleteckova, K. Vales, E. Mezeiova, E. Uliassi, M. Valis,

E. Nepovimova, M.L. Bolognesi, K. Kuca, Eur. J. Med. Chem. 168 (2019) 491-514.

[15] K. Spilovska, J. Korabecny, E. Nepovimova, R. Dolezal, E. Mezeiova, O. Soukup,

K. Kuca, Curr. Top. Med. Chem. 17 (2017) 1006-1026.

[16] A. Hiremathad, R.S. Keri, A.R. Esteves, S.M. Cardoso, S. Chaves, M.A. Santos, Eur. $\mathrm{J}$.

Med. Chem. 148 (2018) 255-267.

[17] L. Piemontese, D. Tomás, A. Hiremathad, V. Capriati, E. Candeias, S.M. Cardoso, S. Chaves, M.A. Santos, J. Enzyme Inhib, Med. Chem. 33 (2018) 1212-1224.

[18] W.L.F. Armarego, D.D. Perrin, Purification of Laboratory Chemicals, fourth ed., Butterworth-Heinemann, Oxford, 1999.

[19] G. Kryger, I. Silman, J.L. Sussman, Structure Fold. Des. 7 (1999) 297-307 http:// www.rcsb.org/pdb/explore/explore.do?structureId=1EVE.

[20] Maestro, version 9.3, Schrödinger Inc., Portland, OR, 2012.

[21] T. Hassinen, M.J. Peräkylä, J. Comput. Chem. 22 (2001) 1229-1242.

[22] M. Clark, R.D. Cramer III, N.J. Van Opdenbosch, J. Comput. Chem. 10 (1989) 982--1012.

[23] G. Jones, P. Willett, R.C. Glen, A.R. Leach, R. Taylor, J. Mol. Biol. 267 (1997) $727-748$.

[24] QikProp, version 2.5, Schrödinger, LLC, New York, NY, 2005.

[25] F.J.C. Rossotti, H. Rossotti, J. Chem. Ed. 42 (1965) 375-378.

[26] A. Gans, A. Sabatini, A. Vacca, Talanta 43 (1996) 1739-1753.

[27] L. Zékány, I. Nagypál, G. Peintler, PSEQUAD version 5 (2001) 01.

[28] K.N. Raymond, C.J. Carrano, Acc. Chem. Res. 12 (1979) 183-190.

[29] A. Rockenbauer, L. Korecz, Appl. Magn. Reson. 10 (1996) 29-43.

[30] R.G. Parr, W. Yang, Density Functional Theory of Atoms and Molecules, Oxford 
University Press, New York, 1989.

[31] M.J. Frisch, G.W. Trucks, H.B. Schlegel, G.E. Scuseria, M.A. Robb, J.R. Cheeseman,

J.A. Montgomery Jr., T. Vreven, K.N. Kudin, J.C. Burant, J.M. Millam, S.S. Iyengar, J. Tomasi, V. Barone, B. Mennucci, M. Cossi, G. Scalmani, N. Rega, G.A. Petersson, H. Nakatsuji, M. Hada, M. Ehara, K. Toyota, R. Fukuda, J. Hasegawa, M. Ishida, T. Nakajima, Y. Honda, O. Kitao, H. Nakai, M. Klene, X. Li, J.E. Knox, H.P. Hratchian, J.B. Cross, V. Bakken, C. Adamo, J. Jaramillo, R. Gomperts, R.E. Stratmann, O. Yazyev, A.J. Austin, R. Cammi, C. Pomelli, J.W. Ochterski, P.Y. Ayala, K. Morokuma, G.A. Voth, P. Salvador, J.J. Dannenberg, V.G. Zakrzewski, S. Dapprich, A.D. Daniels, M.C. Strain, O. Farkas, D.K. Malick, A.D. Rabuck, K. Raghavachari, J.B. Foresman, J.V. Ortiz, Q. Cui, A.G. Baboul, S. Clifford, J. Cioslowski, B.B. Stefanov, G. Liu, A. Liashenko, P. Piskorz, I. Komaromi, R.L. Martin, D.J. Fox, T. Keith, M.A. Al-Laham, C.Y. Peng, A. Nanayakkara, M. Challacombe, P.M.W. Gill, B. Johnson, W. Chen, M.W. Wong, C. Gonzalez, J.A. Pople, Gaussian 03, Revision C.02, Gaussian, Inc., Wallingford CT, 2004.

[32] J.P. Perdew, K. Burke, Y. Wang, Phys. Rev. B 54 (1996) 16533-16539.

[33] K.D. Dobbs, W.J. Hehre, J. Comp. Chem. 8 (1987) 861-879.

[34] P.C. Hariharan, J.A. Pople, Theor. Chim. Acta 28 (1973) 213-222.

[35] J. Sebestík, S.M. Marques, P.L. Falé, S. Santos, D.M. Arduíno, S.M. Cardoso, C.R. Oliveira, M.L. Serralheiro, M.A. Santos, J. Enz. Inhib. Med. Chem. 26 (2011) 485-497.

[36] G.L. Ellman, K.D. Courtney, V. Jr Andres, R.M. Featherstone, Biochem. Pharmacol. 7 (1961) 88-95.

[37] M. Bartolini, C. Bertucci, M.L. Bolognesi, A. Cavalli, C. Melchiorre, V. Andrisano, ChembioChem 8 (2007) 2152-2161.

[38] X. Chao, X. He, Y. Yang, X. Zhou, M. Jin, S. Liu, Z. Cheng, P. Liu, Y. Wang, J. Yu, Y. Tan, Y. Huang, J. Qin, S. Rapposelli, Bioorg. Med. Chem. Lett. 22 (2012) 6498-6502.

[39] T. Mosmann, J. Immunol. Methods 65 (1983) 55-63.

[40] S. Chaves, A. Hiremathad, D. Tomás, R.S. Keri, L. Piemontese, M.A. Santos, New $\mathrm{J}$.

Chem. 42 (2018) 16503-16515. 
[41] G. Coban, L. Carlino, A.H. Tarikogullari, S. Parlar, G. Sarikaya, V. Alptuzun, A.S. Alpan, H.S. Gunes, E. Erciyas, Med. Chem. Res. 25 (2016) 2005-2014.

[42] J. Cheung, M.J. Rudolph, F. Burshteyn, M.S. Cassidy, E.N. Gary, J. Love, M.C. Franklin, J.J. Height, J. Med. Chem. 55 (2012) 10282-10286.

[43] C. Rodríguez-Rodríguez, N.S. de Groot, A. Rimola, A. Álvarez-Larena, V. Lloveras, J. Vidal-Gancedo, S. Ventura, J. Vendrell, M. Sodupe, P. González-Duarte, J. Am, Chem. Soc. 131 (2009) 1436--1451.

[44] S. Conchinhas, MSc Thesis, IST, May, 2017.

[45] T. Leininger, A. Nicklass, H. Stoll, M. Dolg, P. Schwerdtfeger, J. Chem. Phys. 105 (1996) 1052-1059.

[46] C. Quintanova, R.S. Keri, S.M. Marques, M.G. Fernandes, S.M. Cardoso, M.L. Serralheiro, M.A. Santos, MedChemComm 6 (2015) 1969-1977.

[47] C.C. Tan, J.T. Yu, H.F. Wang, M.S. Tan, X.F. Meng, C. Wang, T. Jiang, X.C. Zhu, L. Tan, J. Alzheimers Dis. 41 (2014) 615--631.

[48] P. Faller, C. Hureau, Dalton Trans. 7 (2009) 1080-1094. 